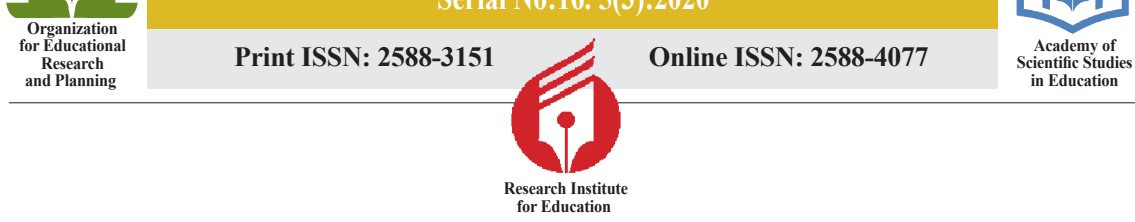

\title{
The Structural Relationships of the Islamic Lifestyle and the Academic Success with the Mediation through Adaptation to School
}

Fahimeh Askari ${ }^{1}$, Alireza Manzari Tavakoli ${ }^{2}$, Hamdollah Manzari Tavakoli ${ }^{3}$, Zahra Zeinodini ${ }^{4}$

- Objective: This study seeks to investigate the structural relationships of the Islamic lifestyle and the academic success with the mediation through adaptation to school using the structural equation modeling.

- Method: The statistical population of the study was 7370 students, all senior secondary school students in Kerman, Iran. From among this population, 380 people (220 girls and 160 boys) were selected as a sample using the stratified random sampling method, and they answered three questionnaires: Kaviani's Islamic Lifestyle (2012), Salehi's Academic Success (2014), and Sinha's and Singh's Adjustment Inventory for School Students (1993). Data analysis was performed by path analysis method of structural equation modeling by the software of SPSS22 and AMOS16.

- Findings: The findings showed that the path coefficient between the Islamic lifestyle variable and academic success in the complete-effect model without a mediating variable was significant. Furthermore, these findings confirmed the direct effect of Islamic lifestyle on academic success, and the variable of the adaptation to school mediated this relationship.

- Conclusion: Accordingly, to increase these two characteristics, it can be suggested that measures be taken to promote the components of the Islamic stylization of students.

Keywords: Islamic lifestyle, academic success, adaptation to school.

Citation: Askari,F., \& Manzari Tavakoli,A., \& Manzari Tavakoli, H., \& Zeinodini,Z. (2020). The Structural Relationships of the Islamic Lifestyle and the Academic Success with the Mediation through Adaptation to School. Applied Issues in Islamic Education, 5(3): 101-126.

1. A Ph.D. Student in Educational Psychology, the Psychology Department, Islamic Azad University, Kerman Branch, Kerman, Iran.

E-mail: askari.f69@yahoo.com. (iD) 0000-0001-8627-5438

2. Corresponding Author: An assistant professor in the Philosophy of education, Psychology Department, Islamic Azad University, Kerman Branch, Kerman, Iran..

E-mail: manzari.a@gmail.com. (iD) 0000-0002-0325-3450

3. An assistant professor in the Philosophy of education, Psychology Department, Islamic Azad University, Kerman Branch, Kerman, Iran..

E-mail: manzari_h33@yahoo.com. (iD) 0000-0001-8618-5743

4. An assistant professor, the educational Psychology Department, Islamic Azad University, Kerman Branch, Kerman.

E-mail: z.zeinadini@gmail.com. (DD 0000-0001-3547-0691 


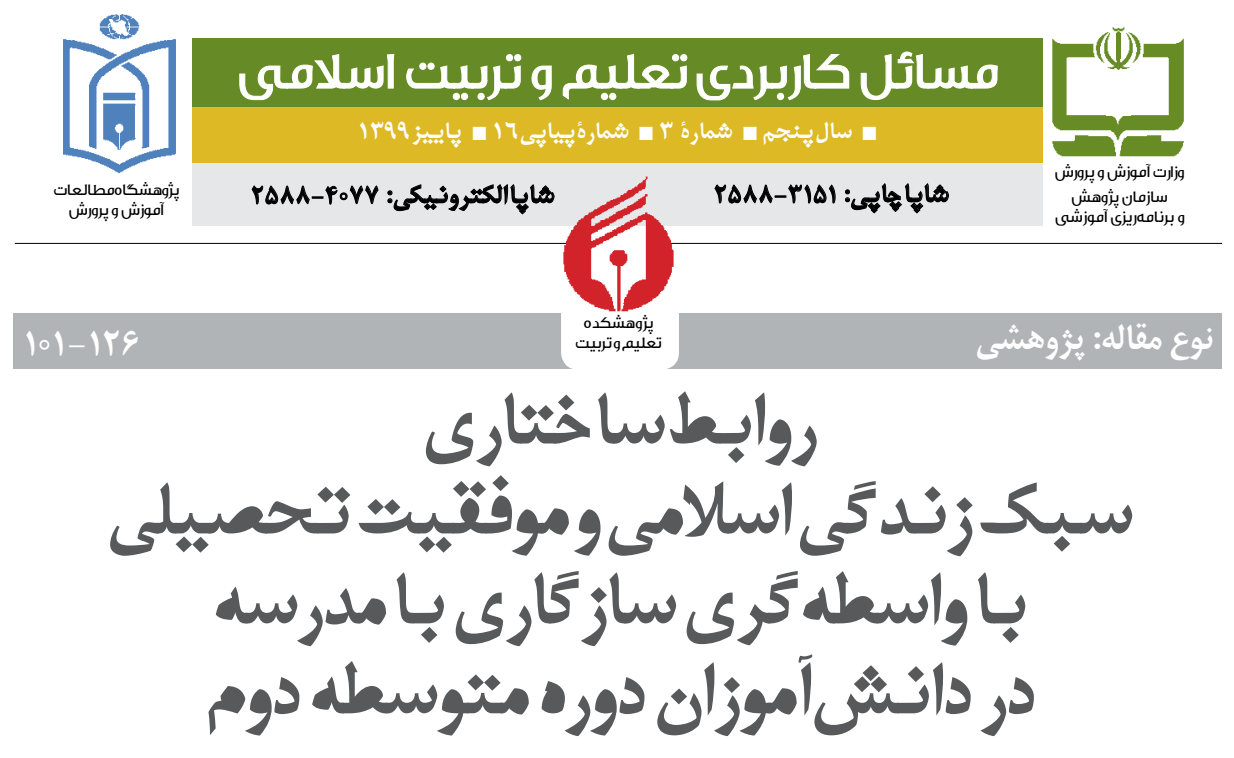

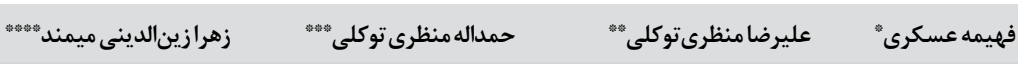

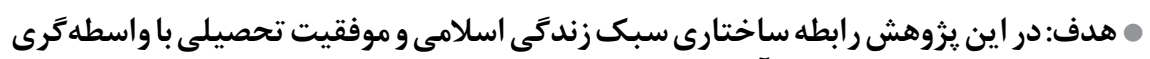

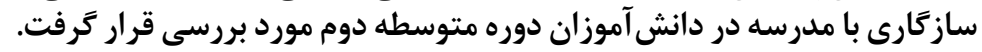

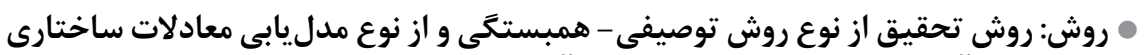

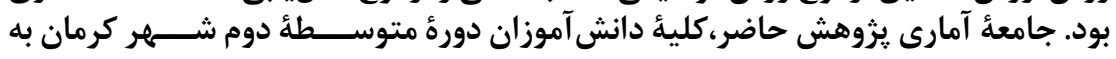

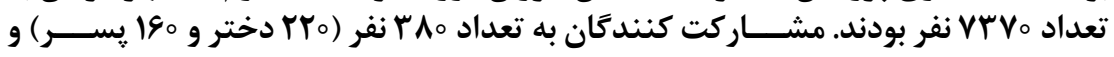

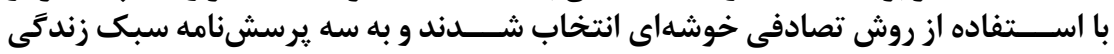

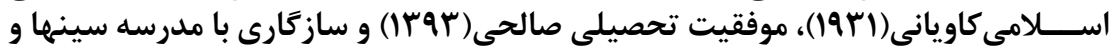

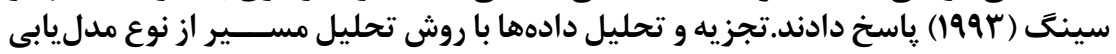

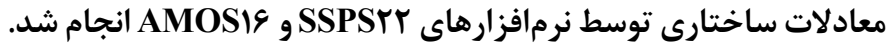

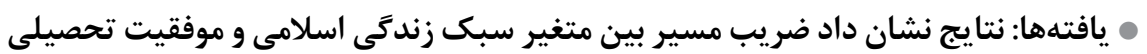

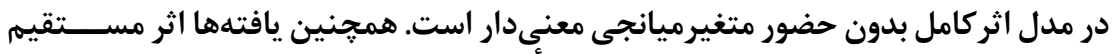

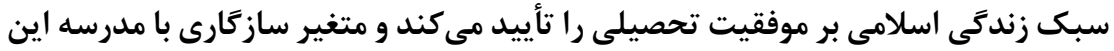

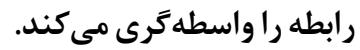

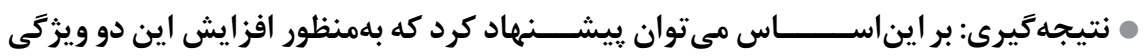

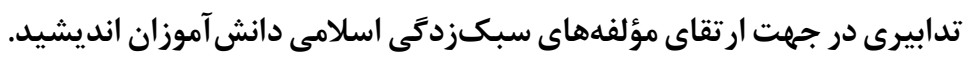

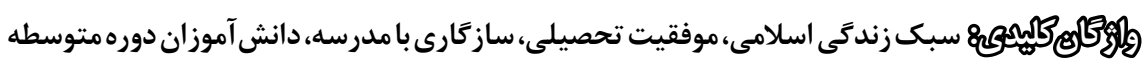

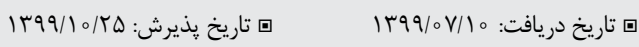

* دانشجوى دكتراى روانشناسى تربيتى، كروه روانشناسى، دانشكده ادبيات و علوم انسانى، دانشعاه آزاد اسلامى، واحد كرمان، ايران. Email: askari.f69@yahoo.com (DD 0000-0001-8627-5438

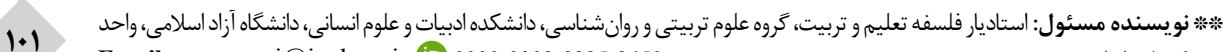
Email: a.manzari@iauk.ac.ir (D) 0000-0002-0325-3450

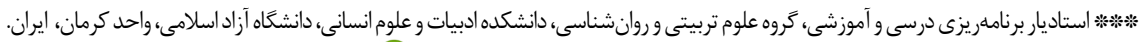
Email: manzari_h33@yahoo.com (DD 0000-0001-8618-5743 


\section{مقدمه}

موفقيت تحصيلى دانش آموزان، يكى از اهداف مههم در نظام آموزشى است. دانش آموزان موفق بهخوبى مى دانند كه جطور در مواقع ضرورى بر مطالعهُ خود تمركز كنـد و هر زمان

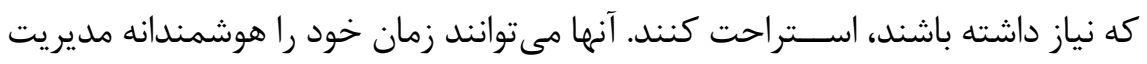
كنند، برنامههاى مطالعهُ هدفمند دارند و از زمان خود در كلاس درس، بهترين استفاده را ببرند (Alyahyan \& Dustegor, 2020). مطالعه، اولويت اول دانشآموزان موفق اســــ مـان. آنها از انكَيزء درونى بالايى برخوردارند و اشــتياق به مدرســهـ در ســـح بالايى در آنها

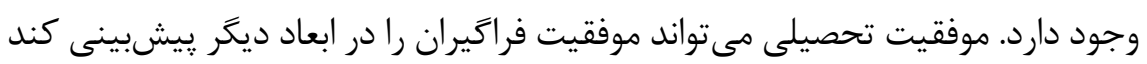

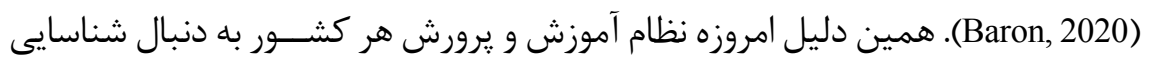
عوامل مؤثر بر فرايند يادگيرى، ياددهى و به تبع آن عملكرد و ييشرفت تحصيلى فراخيران

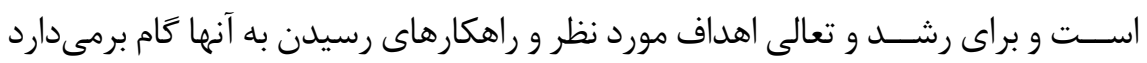
(قوامى، عابدى و نيلفروشان، وجس |). موفقيت تحصيلى و عوامل مؤثر بر آن همواره مورد توجه متخصصان آموزش و يرورش و محققان حوزه آموزشى و تحصيلى بوده و تحقيقات بسيارى را به خود اختصاص داده است. موفقيت تحصيلى بلمعناى توانايى اثبات موفقيت، در اكتساب ييامدى است كه براى آن طرحريزى و برنامهريزى شده است (Yusuf, 2011). فراخير با كسب موفقيت تحصيلى، مورد تأييد و يذيرش همسالان و معلمان و والدين قرار مى كيرد و عزت نفس و احساس كفايت و لياقت او بيشتر مى شود، در مقابل فرد با شكست تحصيلى به توانايى و كفايت خود شك مى كند و احساس بى كفايتى و بـىلياقتى و حقارت

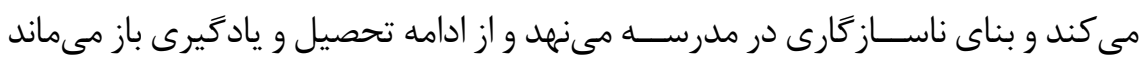

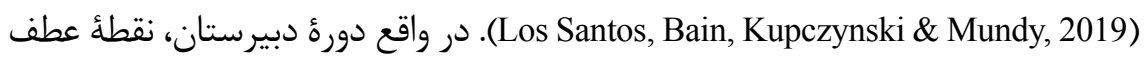
مهمىاز رشد نوجوان و ويشبينيكنندهُ مهمىاز موفقيت آينده و بهزيستى و سلامت فرد مىباشد (Chun \& Dickson, 2011). موفقيت تحصيلى نه تنها شرايط استخدام و موفقيت

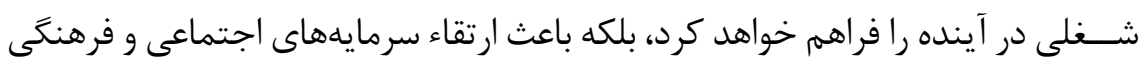
و زندكى اســتاندارد خواهد شد و سلامت بيشتر نســبت به ديخران را به ارمغان خواهد

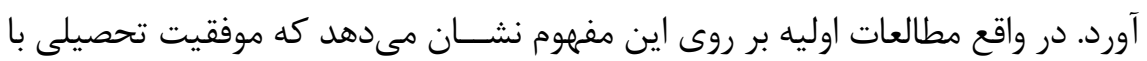
مفاهيمى جون ييشرفت تحصيلى و عملكرد تحصيلى يكسان در نظر گرفته شده است و ميانگين نمرات درســى يا معدل، معمولترين ابزار موفقيت تحصيلى دانشآموزان است 


\section{$101-159$}

(Usher, Li, Butz \& Rojas, 2019). بعضــى از تحقيقات نيز ملاك هاى ديخرى به معدل اضافه كرده و آنها را نشانهٔ موفقيت تحصيلى معرفى كردهاند. برخى خوديندارهُ (اتوانايى)"

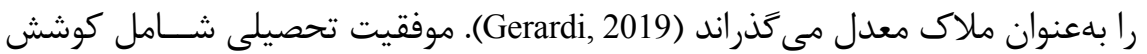

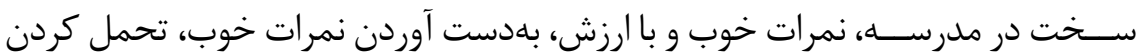
جنبههاى منفى مدرســهـ و ييشبينى اتمام تحصيلات در مقاطع تحصيلى بالاتر اســت (Deaton, 2008). موفقيت تحصيلى شــامل سه جز ييشــــفت، رضايت و تداوم انخيزش مىباشد (Artino, 2009). تعاريف موفقيت تحصيلى را مىتوان در دو دسته بزرگ شامل تعاريف بزرى عينى و ذهنى جاى داد كه شامل نمرات علمى

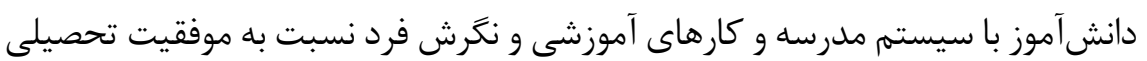
خود مىباشد (Kobal \& Musek, 2001). يزوهش هايى كه در جزند دهه اخير در مورد موفقيت تحصيلى انجام شــده نشـــان داده است كه عوامل بسيارى در موفقيت يا عدم موفقيت دانشآموزان در تحصيل، تأثير دارند. يكى از عواملى كه در موفقيت تحصيلى دانشآموزان مؤثر اســـ، ســبك زندكى

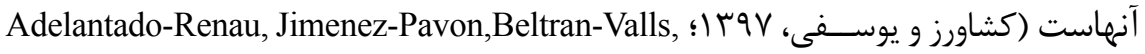

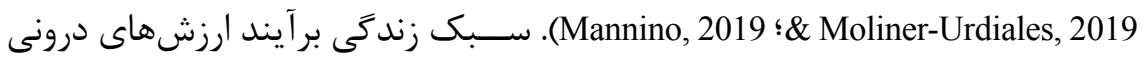
شده فرد اســت؛ مجموعهاى از ارزشها در فرد درونى مىشود و فرد را ناگزير مى كند

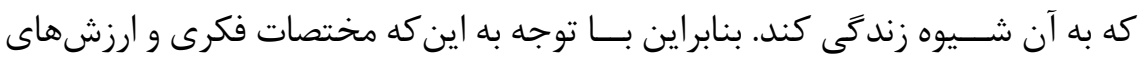
درونى شــده افراد باهم متفاوتاند، سبكهاى مختلفى نيز براى زندگى وجود دارد. به ديخر تعبير، افراد از مبانى اعتقادى، فرهنگَى يكسانى ييروى نمى كنند و به دليل تنوع در دنياى مدرن، خردهفرهنَتهاى بســيارى درون هر نظام فرهنگَى ديده مىشود. اين خردهفرهنگ ها و الگوهاى رفتارى در گذشته، بسته به گروههاى نزادى، دينى، قومى و طبقاتى متفاوت بود، اما امروزه دامنه اين تكثر وتنوع بســيار گستردهتر است و جامعه انسانى به گروههايى مبدل شده كه هريك، از لحاظ باورها، ارزشها، نخرشها، آرمانها و نيازها متفاوت و متمايز هستند، اين تمايزها در سبك زندگى بروز و تجلّى مى يسّابد و اين گونه است كه با انواع سبك زندگى روبلرو هستيهم (شريفى، (|qسا). در اين راستا،

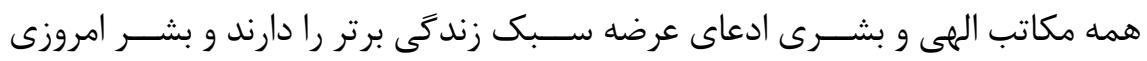
بهموازات رشــد تكنولوزى، در اين آشــفتهبازار مكاتب، در سرگردانى و حيرانى به سر 
مىبرد. اين در حالى اسـت كه اسلام بهعنوان كاملترين دين آسمانى با توجه به آيات

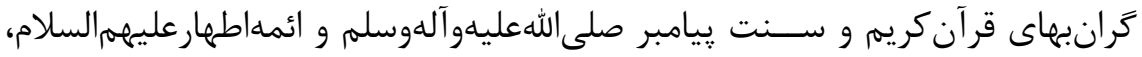

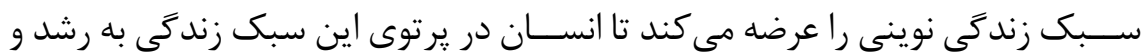

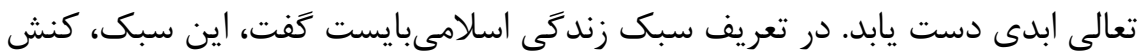

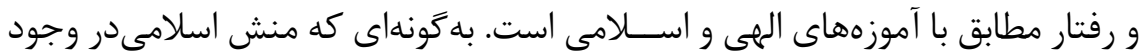

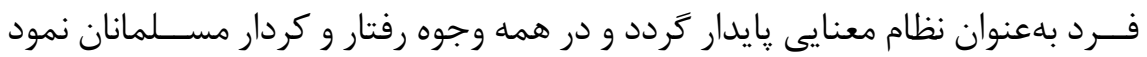
يابد. سبك زندگى اسلامىاز آن جهت كه سبك است، به رفتار و اعمال مىيردازد و با نهاي

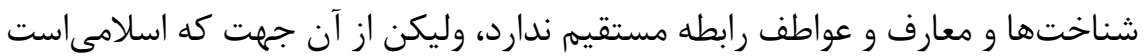

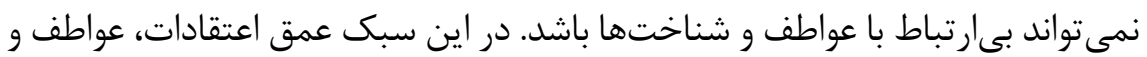

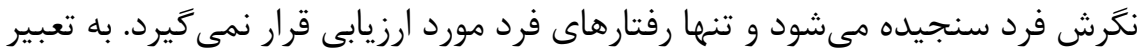

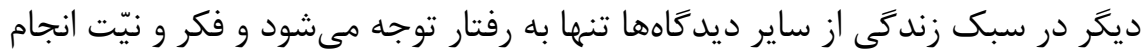

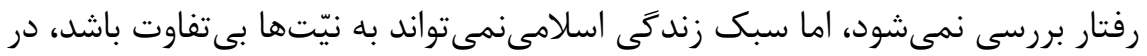

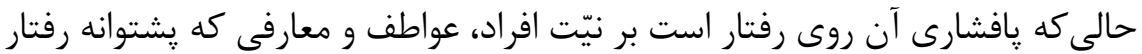

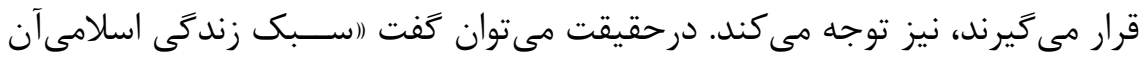

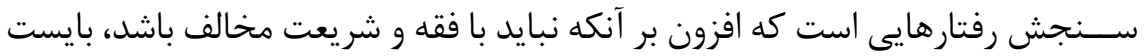

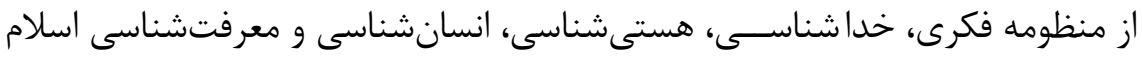

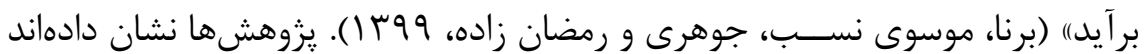

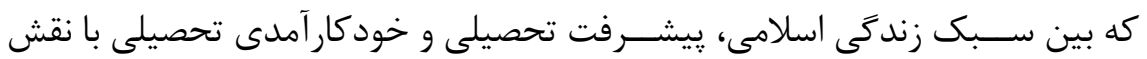

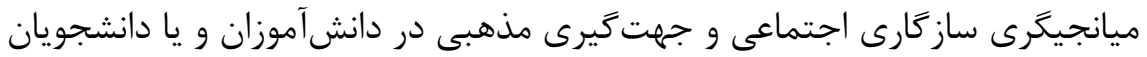

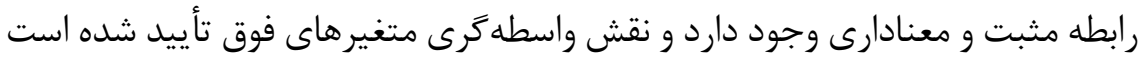

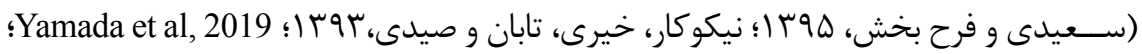

.(Mannino et al, 2019

ســـبك زندگى اســلامى، مجموعهاى از مهارتهاى هماهنَ هويت ساز متأثر از

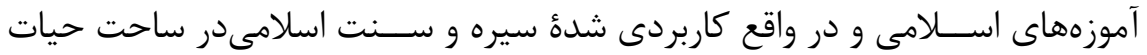

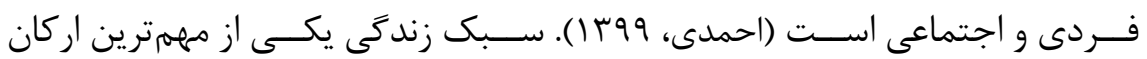

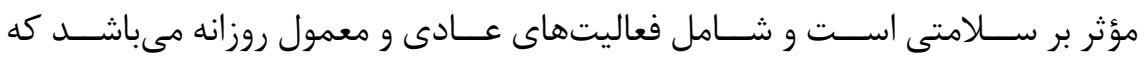

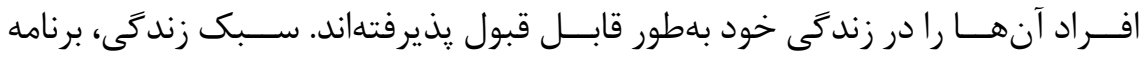




\section{$101-149$}

زندگَى، راهبردى براى زيســتن يا نقشـــه راه زندكى، شــيوه منحصر بـــه فرد تفكر،

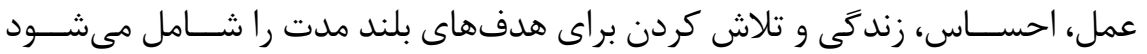

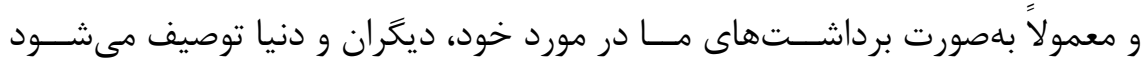
(Yamada, Sekine, Tatsuse \& Asaka, 2019) زندگَى مىتوان به فعاليتهاى فيزيكى، اوقات فراغت، خواب و بيدارى، روابط اجتماعى، روابط خانوادكى، معنويت، ايمنى و آرامش، تغذيه و غيره اشاره كرد كه هر كدام به منزله

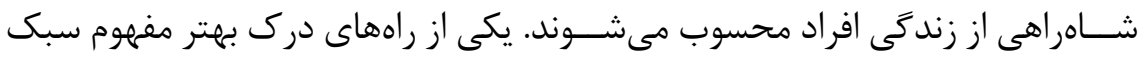
زندگَى، بررسى عناصر و مؤلفههايى است كه براى سبك زندگى در نظر گرفته شدهاند

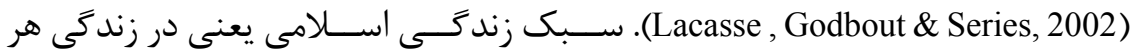

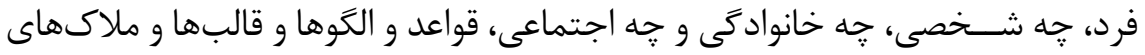
اسلامىنقش مهمى ايفا كند؛ يعنى روش ها را بر اساس آنجه اسلام كَفته و خواسته است به كار گيرد. مفهوم سبك زندگى اسلامى با مفهوم سبك زندگى، كه آدلر بيان مى كند،

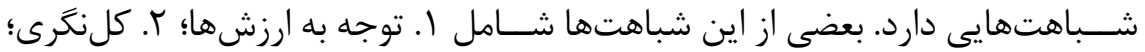

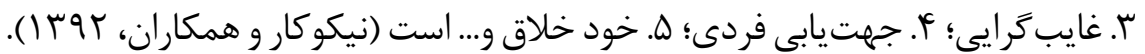
سبك زندگى اســلامى با تمام زندگى افراد و ابعاد آن مرتبط است. در جامعهشناسى، مديريت، علوم يزشكى وروانشناسى بالينى و... نيز بحث از سبك زندگَى مطرح است؛ اما در اين قلمروها فقط به رفتارى خاص مىيردازند و با شــناختها و عواطف ارتباط مســتقيهم برقرار نمى كنـند. اما ســـــ زندگى اســلامى به اين دليل كه اسلامى است، نمى تواند با عواطف و شناختها بىارتباط باشد. براين اســاس هر رفتارى كه بخواهد مبناى اسـلامى داشته باشد، بايد حداقلهايى از شناخت و عواطف اسلامى را تشتوانه

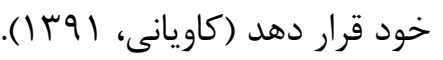

مشـــكلات دانشآموزان در فرايند تحصيل ناشى از سبك زندگى معيوب آنهاست كه ســبـب مىشــود آنها در زمينهُ يكى از مهممترين تكاليــف زندگى - تحصيل عام و

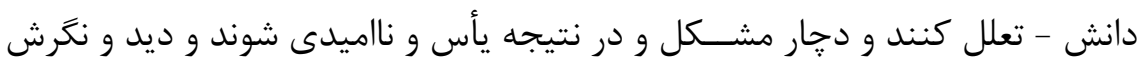
آنها نســبت به تحصيل تغيير كند و فعاليتهاى آنها به گونه ایى انجام شــوند كه از مســـير درس خارج شـــوند و دجار دور باطل نخواستن و نتوانستن در فرايند تحصيل 


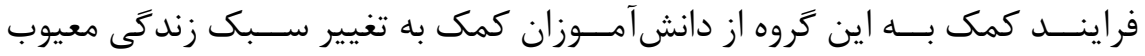

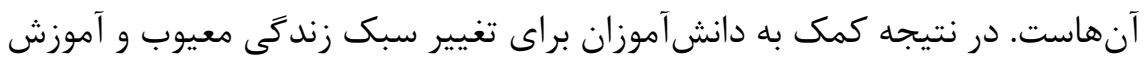

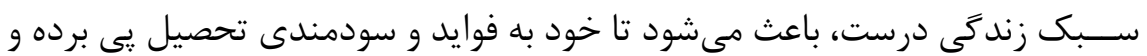

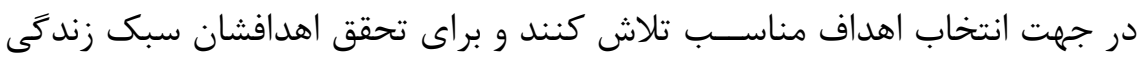

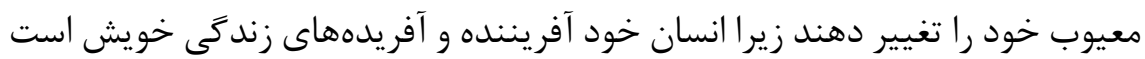

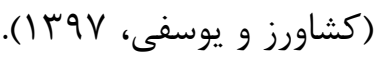

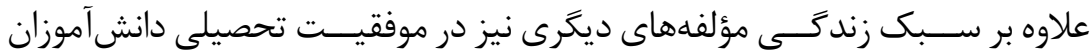

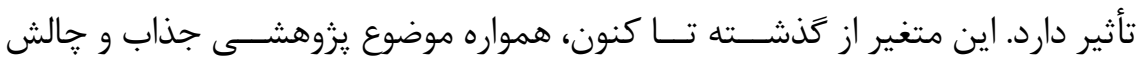

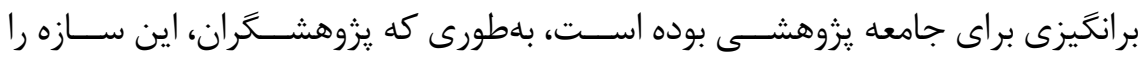

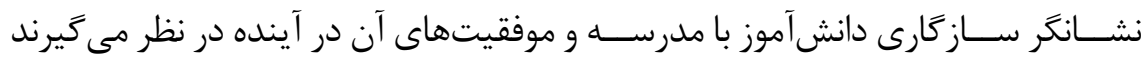

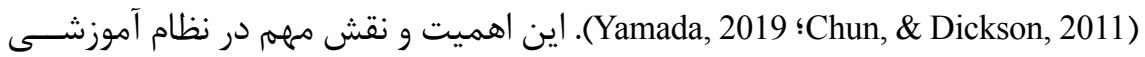

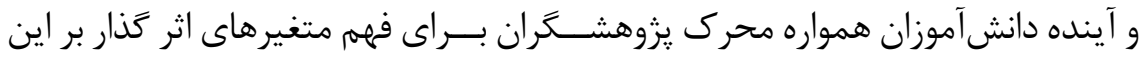

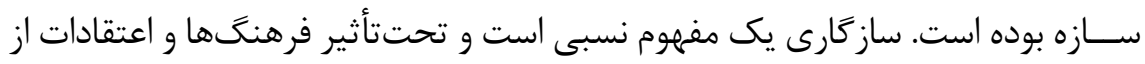

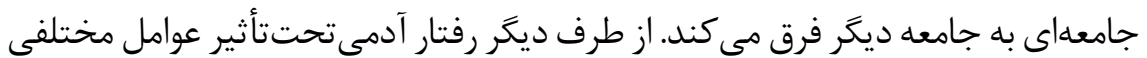

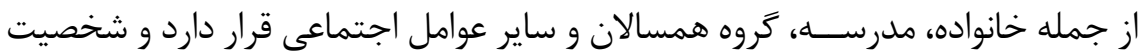

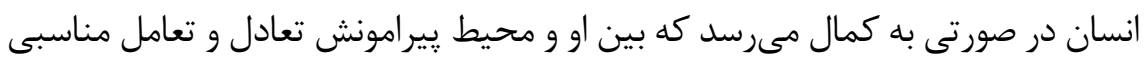

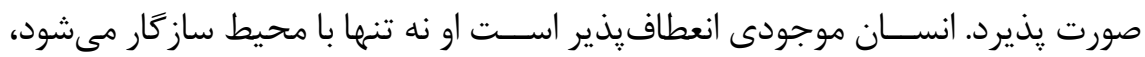
بلكه محيط را بر طبق خواستههاى خود دَر كون مى كند؛ بنابراين ساز گارى و هماهنگ

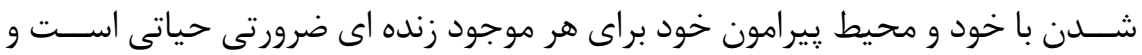

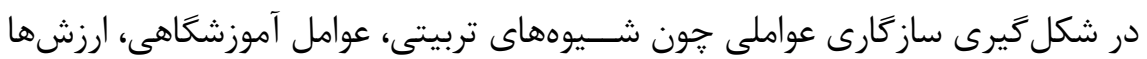

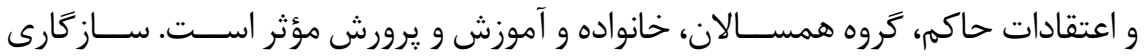

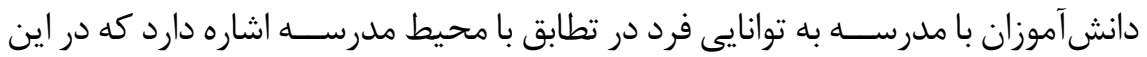

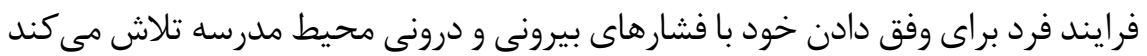

(Gopalan, Beutell \& Middlemiss, 2019)

يكى از ويزگى هاى شــخصيتى كه نقش عمدهاى در بقاى انسان و سلامت روانى او

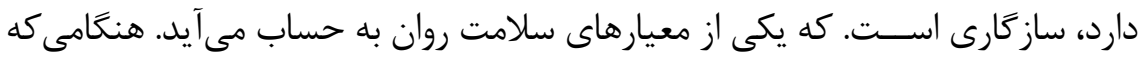

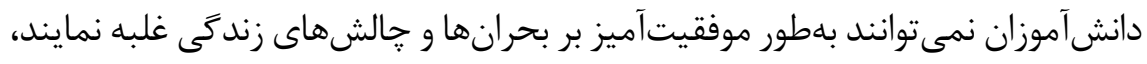




\section{$101-149$}

يريشانى هاى روانشناختى را تجربه خواهند نمود و در گير اختلال هاى عاطفى، اجتماعى

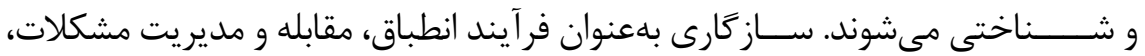

ســاز Fارى عبارت است از ثبات عاطفى و جسارت در روابط اجتماعى و نيز علاقه به تحصيل و مدرسه در فرد كه بهصورت سازگارى عاطفى، ساز ₹ارى اجتماعى و ساز ₹ارى

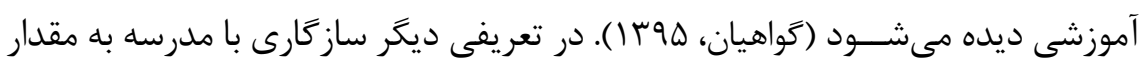
انطباق فرد با شـــرايط، محيط، انتظارات، درخواستها و ساختارهاى اجتماعى حاكم بر

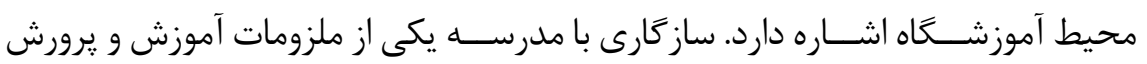

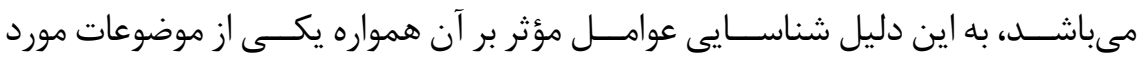
علاقه حوزه روانشناسى مدرســـه بوده است، كه با نشان دادن صلاحيتهاى تحصيلى، اجتماعى - هيجانى و رفتارى مشخص مى شـــود. هر فرد حدود دوازده سال از عمر خود را در محيط مدرســهـه و در ارتباط با همســالان مى كذراند در اين ســال هاى مهرم رشد

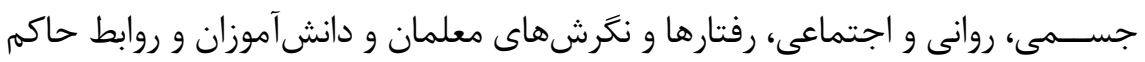

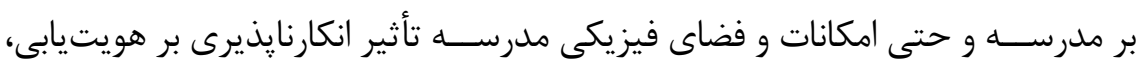
شـــكوفايى استعدادها، يـيشرفت و موفقيت تحصيلم، سلامت جسمانى و روانى افراد دارد

(يور رضوى و حافظيان، ه9 1) ). با توجه به نقش ساز ₹ارى و اين كه نوجوانان در مرحله رشد اجتماعى قرار دارند و در طى آن تلاش آنها براى هماهنگى با محيط به جالش كشــيده مىشود، شناسايى عوامل ييشبينى كنـنده ســاز Fارى موفقيتآميز در مدرسه از اهميت بالايى برخوردار

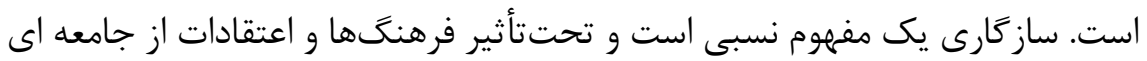
به جامعه ديگر فرق مى كند. ســاز گارى با مدرســهـ يكى از ملزومات آموزش و يرورش مى باشـــد و همواره يكى از موضوعات مورد علاقه حوزه روانشـاسى مدرسه بوده است،

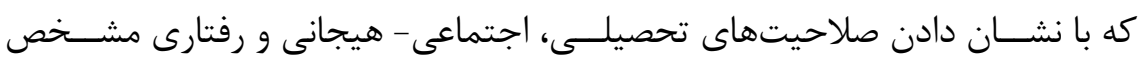

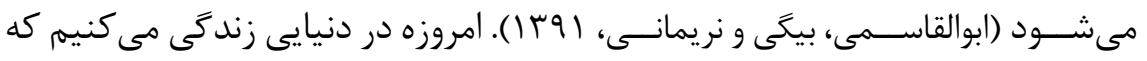

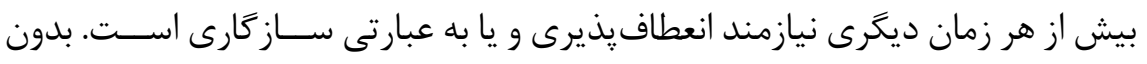
شك ســاز گارى و انعطاف يذيرى مىتواند نقش بهسزايى در زند

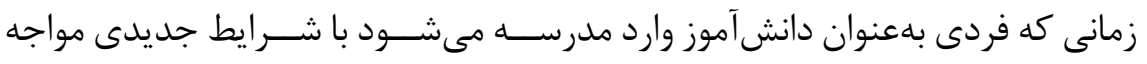


اســت كه بايد خود را با آن منطبق سازد. موقعيت آموزشى و اجتماعى كه دانشآموز در آن قرار مى گيرد يِيجيده، متنوع و گســترده است. لازمه انطباق با اين محيط ترك قســمتى از شـــيوههاى زندكى دوره كودكى و كسب شيوه جديد در شرايط تازه است. ناتوانــى دانش آموز در اين فرايند مى تواند منبع مشــــلات متعدد روحى و روانى براى رهى

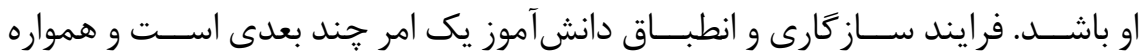
مورد توجه مشاوران و مســـولان آموزشى و انضباطى بوده است. از جمله جالشهايى

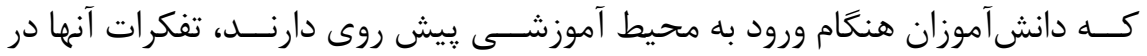
ارتباط با توانايى كنار آمدن با استلزاماتى است كه بر ساز گارىشان تأثير گذار مىباشد

.(Mittelmeier, Rienties, Rogaten, Gunter \& Raghuram, 2019) بـــا توجه به مطالبى كه كَفته شــد، در عصر حاضر تعليــم و تربيت، و بهطور كلى تحصيل، بخش مهمىاز زندگى افراد را تشكيل مىدهد، علاوه بر اين، كيفيت و كميت

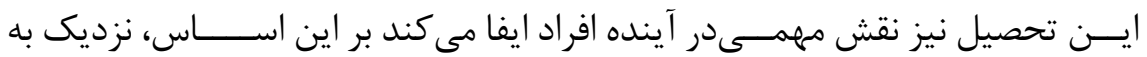
يك قرن اســت كه روانشناســان بهصورت گســـترده در تلاش براى شناسايى عوامل

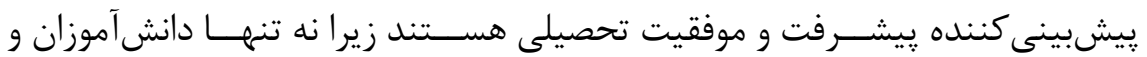
خانـــواده آنها، بلكه جامعه نيــز هزينههاى زيادى در جهت تحصيــلـ دانش آموزان در مقاطع مختلف تحصيلى صرف مى كنند، بنابراين دست يافتن به نتايج مثبت در زمينه

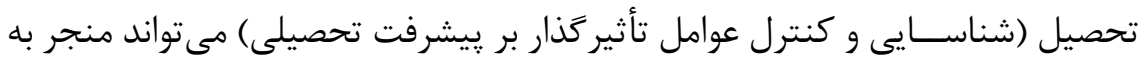
ييشرفت همهجانبه دانشآموزان و جامعه گردد. از آنجا كه دانشآموزان تقريباً نيمىاز روز خود را در مدرســهـ سيرى مى كنـند، لذا شناسايى عوامل مؤثر بر موفقيت تحصيلى، از جمله الزامات نظام آموزش و يرورش مىباشد و نتايج مطالعات موجود نشان مىدهد كه ســــ زندگى دانش آموزان بر سلامت روانشناختى و در نتيجه سازكارى بهتر آنها و موفقيت تحصيلى ايشــان در دورههاى بعدى زندگى تأثير خذار اســت. اما مطالعات اندكـى در خصوص جُكونكى ارتباط اين متغيرها با موفقيت تحصيلى و ســاز گارى با مدرســـه دانش آموزان انجام شده اســت. بنابراين، هدف يزوهش حاضر، بررسى روابط ساختارى سبك زندگى اسلامى و موفقيت تحصيلى با واسطه گرى ساز گارى با مدرسه در دانشآموزان دوره متوسطه دوم بود. 


\section{$101-119$}

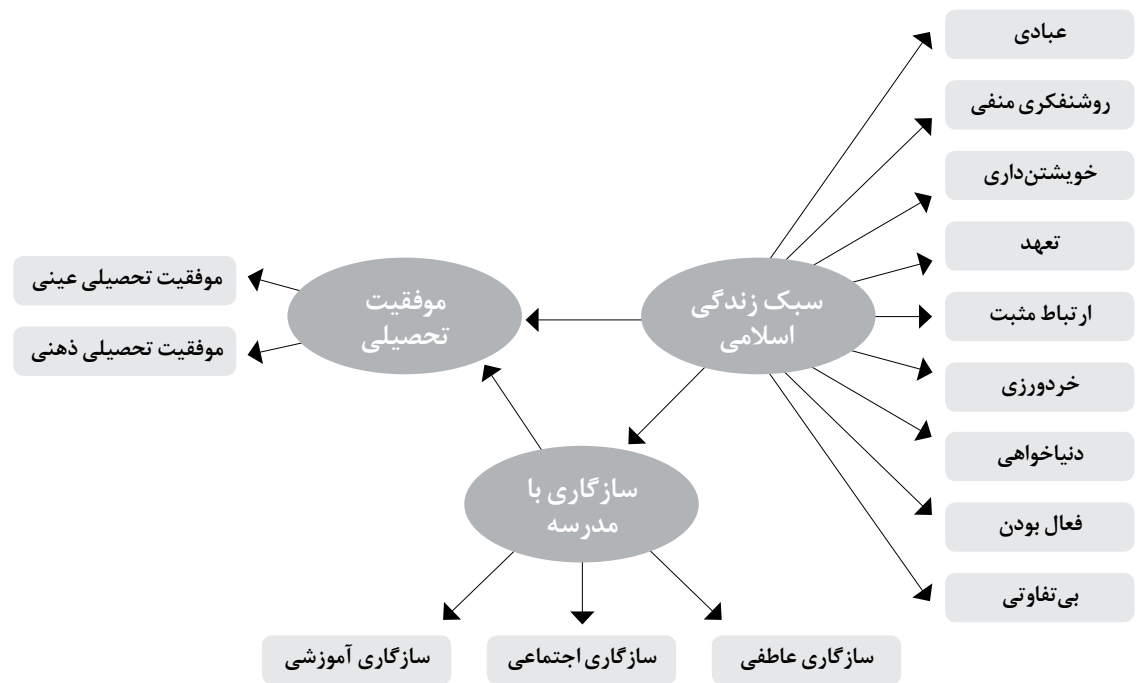

شكل 1. مدل مفهومىيثوهش

\section{روش يزوهش}

دراين يزوهش به بررســـى روابط بين سبك زندگى اسلامى و موفقيت تحصيلى با نقش واســـهةى سازعَارى با مدرسه در دانشآموزان دوره متوسطهُ دوم در دانش آموزان يرداخته شــد. روش تحقيق از نوع روش توصيفى - همبستخى و از نوع مدليابى معادلات ســاختارى بود. جامعهُ آمارى يزوهش حاضر، كلية دانش آموزان دورهُ متوسطة دوم شهر كرمان به تعداد مVV نفر بودند. مشــاركت كنـند

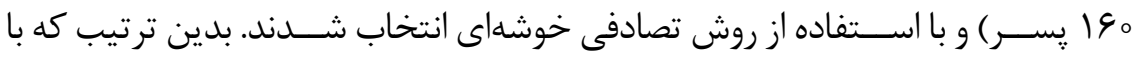
مراجعه به آموزش و يرورش ناحيه يك شهر كرمان ليست مدارس متوسطه دوم و تعداد دانشآموزان هر يك از مدارس را به تفكيك مشخص و با قرعه كشى بين مدارس، بهطور مساوى دبيرستانهاى دخترانه و يسرانه انتخاب شدند. حجم نمونه با توجه به تعداد افراد

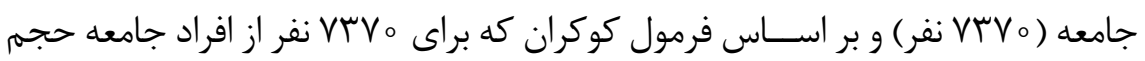
هوب نفر را در نظر گرفته اســت، تعيين شده اســت. با توجه به در نظر گرفتن احتمال

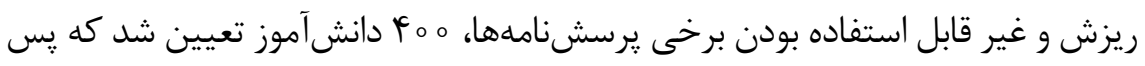

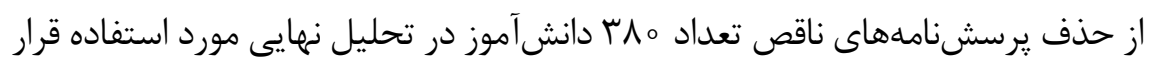




\section{ابزار كَردآورى دادهها در اين يخوهش سه يرسشنامه بود:}

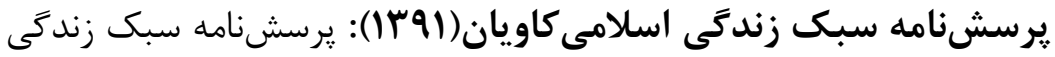

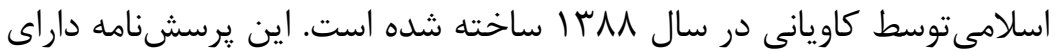

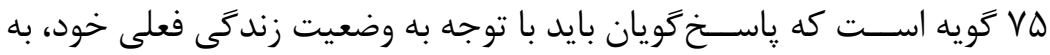

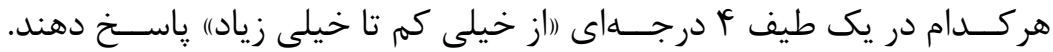

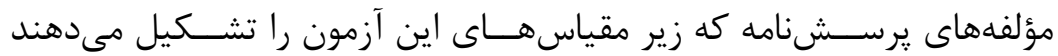

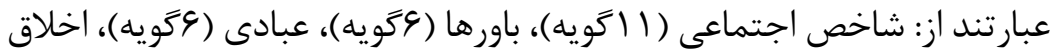

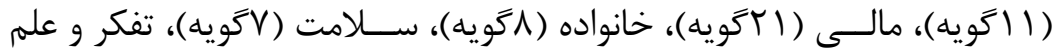

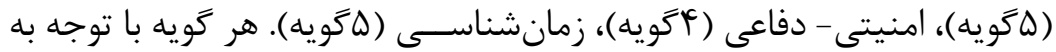

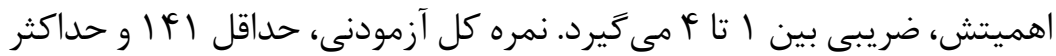

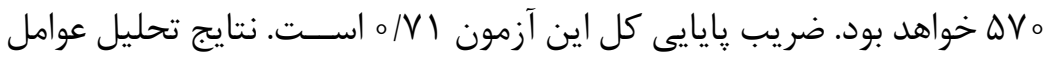

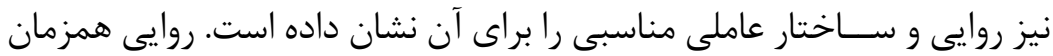

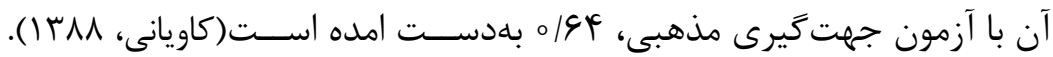

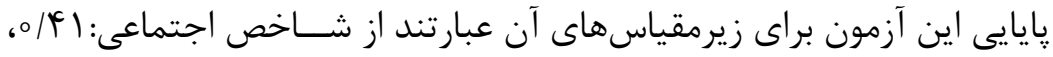

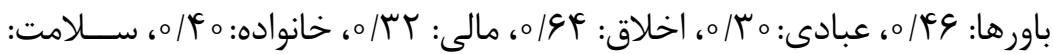

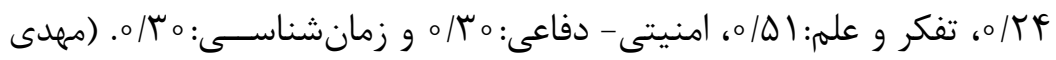

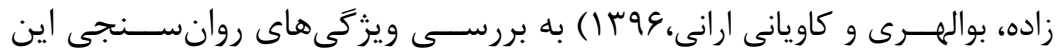

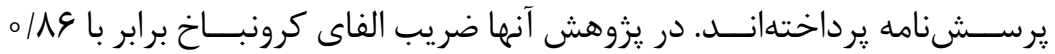

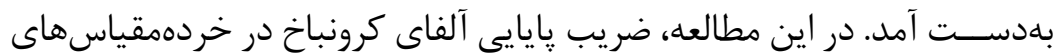
شــاخص اجتماعى، باورها، عبادى، اخلاق، مالى، خانواده، سلامت، تفكر و علم،

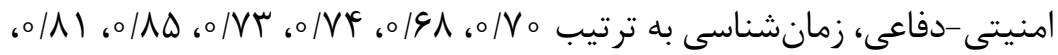

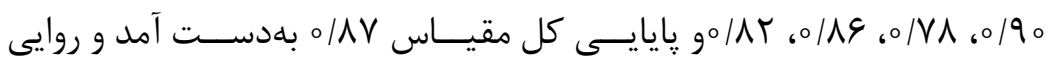

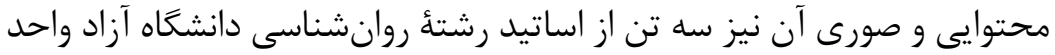
كرمان مورد تأييد قرار كرفت.

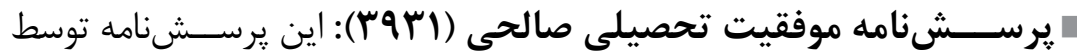
صالحى در ســال بوس ا طراحى شد. اين ابزار داراى هب كويه است كه با استفاده 


\section{$101-119$}

از مقياس ينج درجهاى ليكرت از يك تا ينج نمرهَذارى مىشـــود. نمره اين ابزار

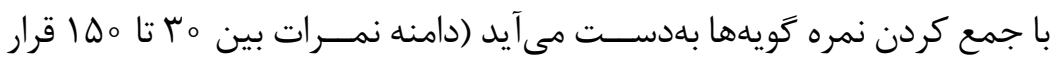
دارد) و هر جه نمره آزمودنى بيشـــتر باشـــ، ميزان موفقيت تحصيلى وى بيشتر اســت. يرسشنامةٔ موفقيت تحصيلى داراى هفت خردهمقياس را تشكيل مى دهد

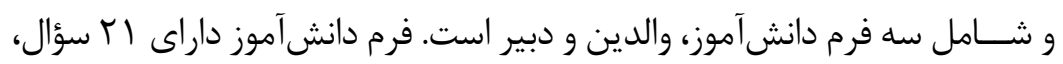
فرم والدين ه ســؤال و فرم معلم ب سؤال اسـت. اين سازه داراى دو بعد عينى و ذهنـــى بوده كه بعد عينى داراى جههـــار خردهمقياس معدل، نظر دانش آموز، نظر والدين و نظر دبيران و بعد ذهنى داراى سه خردهمقياس رضايتمندى، يايستكى و احساس موفقيت تحصيلى بوده كه براى هر خردهمقياس سؤالاتى طراحى شده

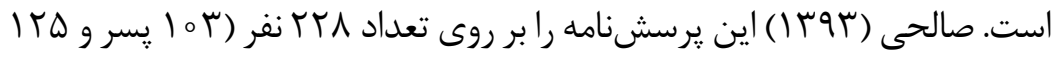
دختر) از دانشآموزان سال اول دبيرستان هاى شهر كرد همراه با يكى از اولياء آنها و همجنين دبيرانشــان اجرا كرد و ويزگگى هاى روانسنجى آن رانيز بررسى نمود. همجنين با استفاده از تحليل عاملى اكتشافى ابزار موردنظر به تأييد دو بعد عينى و ذهنــى و Vخردهمقياس آن يرداخت. صالحـى (بوس ا) ضريب روايى همزمان

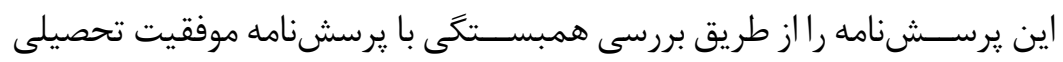

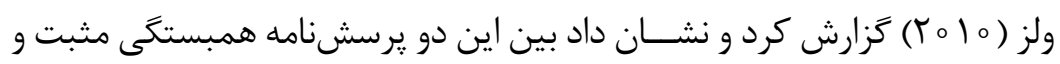

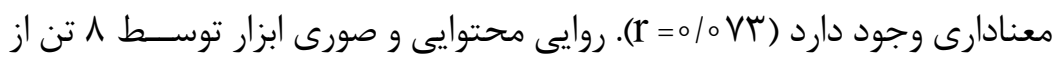

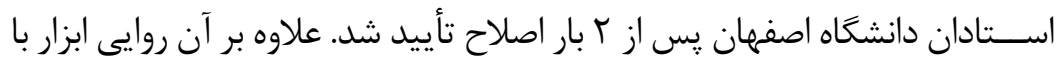
روش همســانى درونى يعنى همبستخگى هر گويه با كل ابزار مناسب گزارش شد. همجنين يايايى ابزار با روشهاى آلفاى كرونباخ و باز آزمايى دو هفتهاى به ترتيب

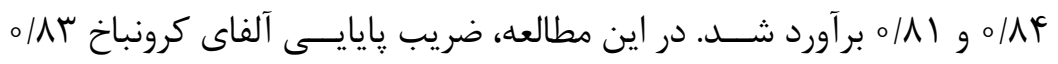

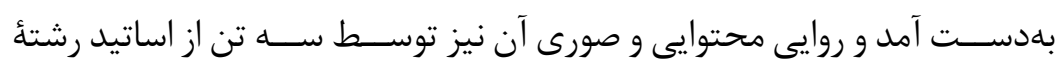
روانشناسى دانشعاه آزاد واحد كرمان مورد تأييد قرار زرفت.

يرسشنامه سازگًارى با مدرسه سينها و سينَ (199): اين :رسشنامه توسط

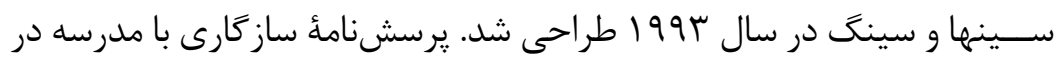

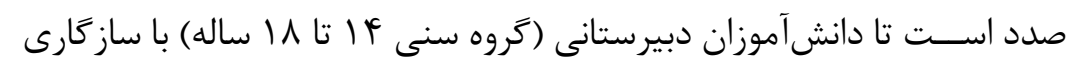
خوب را از دانشآموزانى با ســاز عارى ضعيف در ســـه حوزه عاطفى، اجتماعى و 
آموزشــى جدا سازد. فرم نهايى اين يرسشنامه داراى هو عويه مىباشد كه سه

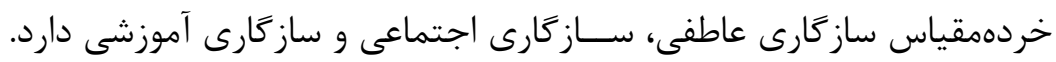

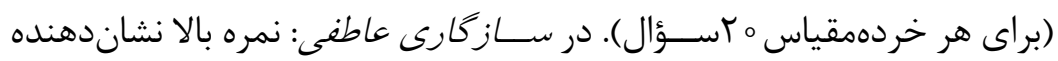
بى ثباتى عاطفى و نمره يايين، نشــانگر ثبات عاطفى است. سازگارى اجتماعى:

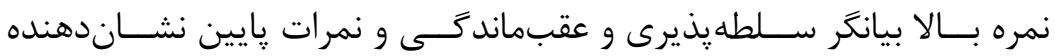

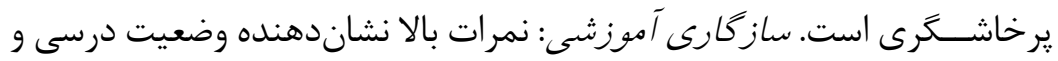
تحصيلى ضعيف و نمرات يايين مخصوص علاقهمندى به تحصيل و مدرسه است. در نمرهگذارى اين يرســشنامه مىتوان بهصورت دســتى نيز نمرهَذارى كرد. براى ياسخهايى كه نشانگر سازگارى است، نمره صفر داده مىشود و در غير اين صورت، ا منظور مىشــود. نمره كل يرسشنامه بيانگر حالتهاى ساز گارى فرد اســت. ميزان ضريب يايايى يرسشنامه با روش دو نيمه كردن در خردهمقياس

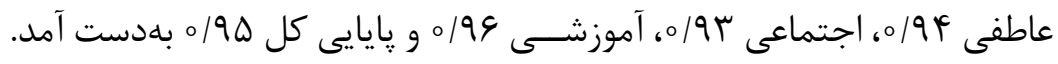
و روايى آن نيز مورد تأييد قرار گرفت (كواهيان، هوسا ). در اين مطالعه، ضريب يايايى آلفاى كرونباخ در خردهمقياسهاى عاطفى، اجتماعى آموزشـى و كل به

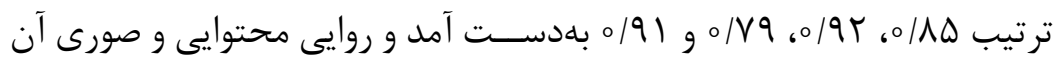
نيز توسط سه تن از اســاتيد رشتهُ روانشناسى دانشعاه آزاد واحد كرمان مورد تأييد قرار كرفت.

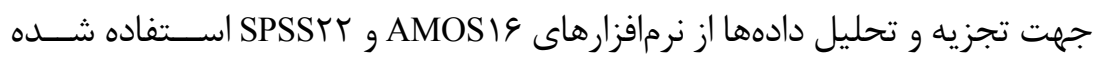

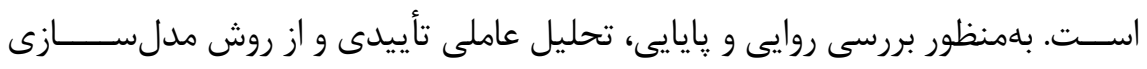

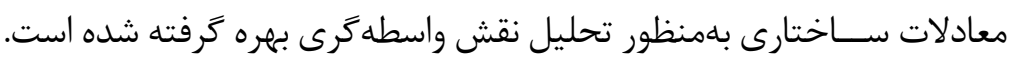

\section{يافتلهاى يخوهش}

براى آزمون نرمال بودن متغيرها، از آزمون جولكى و كشــيدگى استفاده گرديد كه نتايج آن در جدول ا ارائه گرديده است. همان گَونه كه مشاهده مى گردد با توجه به اينكه

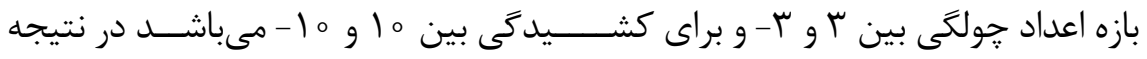
فرض نرمال بودن دادهها مورد تأييد است. 


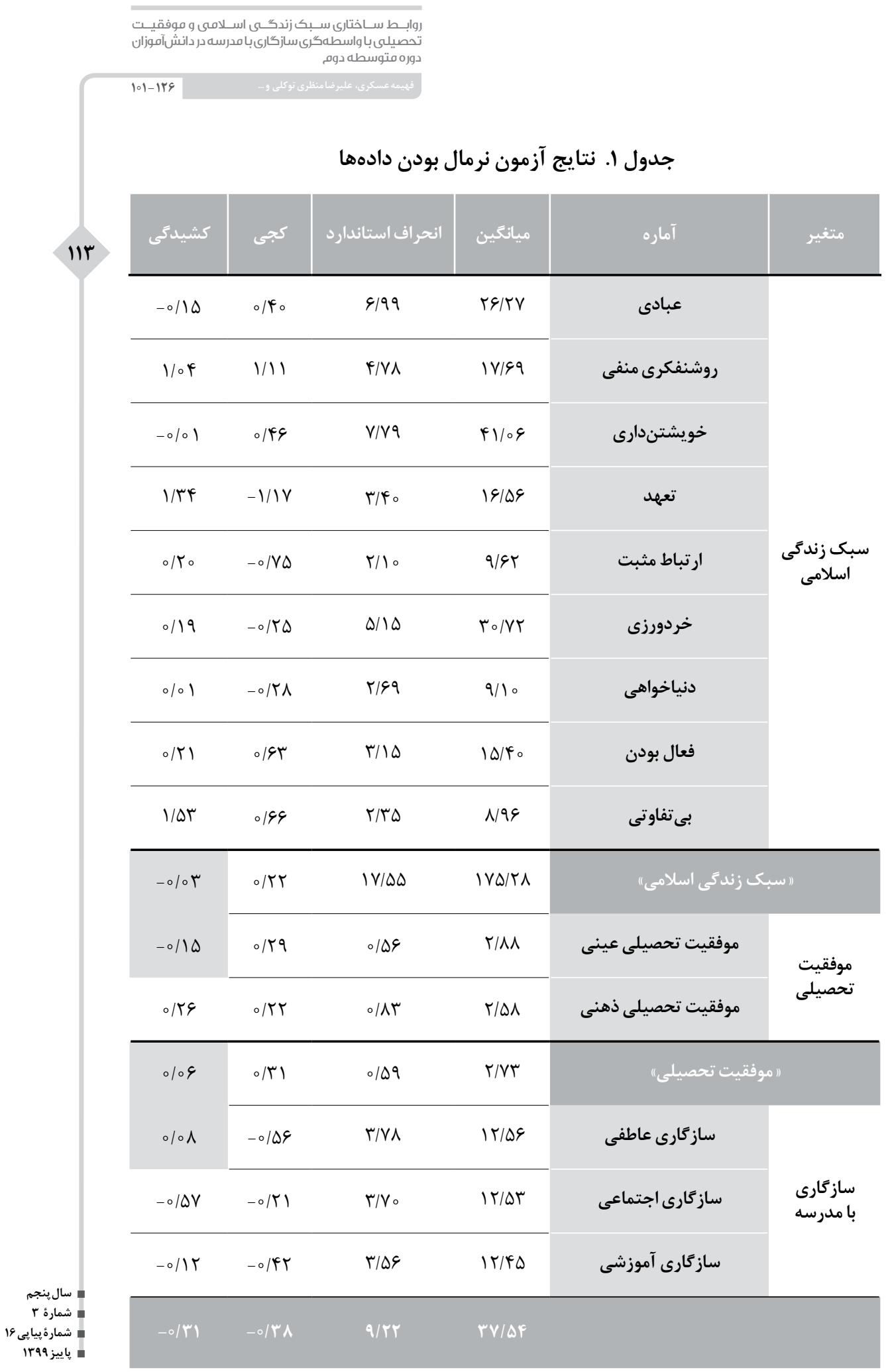


در اين مرحله، تعيين مىشــود كه آيا مفاهيمم نظرى به درســتى توسط متغيرهاى مشاهده شــده اندازهگيرى شدهاند يا خير. بدين منظور روايى و وايايى آنها بررسى مى -

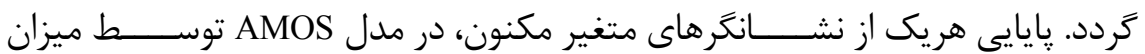
بارهاى عاملى هر نشــانگر مشخص مىشود. ارزش هريك از بارهاى عاملى نشـــانگرهاى متغير مكنون مربوطه ميبايست بزر گتر يا مساوى ه/ه باشد. در اين يزوهش، تمامىمقادير سنجههاى مرتبط با متغير مكنون بالاتر از ه/ه اسـتـ. بنابرايــن مىتوان كفت اين مدل

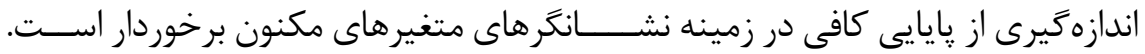
بعد از بررســى نشانگرهاى سازه و اطمينان از شناسايى يذير بودن مدل نوبت به ارزيابى برازش مدل مىرسد (جدول r).

جدول r. شاخص هاى برازش

\begin{tabular}{|c|c|c|c|c|c|c|c|c|c|c|c|c|}
\hline RMSEA & NFI & CFI & TLI & IFI & AGFI & GFI & $\mathbf{P}$ & NPAR & CMIN/DF & DF & CMIN & شاخصنهاى \\
\hline 01091 & o/AV &.$/ 94$ & $0 / 90$ & $0 / 9 T$ & O/AG & $0 / 19$ & 01001 & Vr & $r / \% q$ & $T T V$ & DFT/GG & شرازش \\
\hline$<0 / 01$ & $>0 / 90$ & $>0 / 90$ & $>0 / 90$ & $>0 / 90$ & $>0 / 90$ & $>0 / 90$ & $>010 \Delta$ & - & $<r$ & - & $=\mathrm{df}$ & مطلوب \\
\hline
\end{tabular}

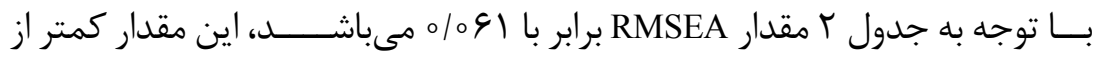
^॰ /ه است كه نشاندهنده اين است كه ميانخين توان دوم خطاها مقدار كمىدارد و مدل قابل قبول مىباشد. همجنين مقدار كاى دو به درجه آزادى بين ا و س مىباشــد و ميزان شاخص CFI نيز از 9/ه بيشتر مىباشد. بهطور كلى زمانى كه حداقل سه شاخص مقاديرى در بازهى قابل قبول داشـــه باشند مىتوانيم ادعا كنيم كه برازش مدل خوب وابل قبول است. پس از اطمينان از مناسب بودن برازش مدل و ارزيابى گايايى و روايى سازهها، مدل را با ييروى از مدل تحقيق براساس آخرين تغييرات در مدل CFA رســم ميكنيه. هدف از اجراى SEM تخمين روابط بين متغيرها و آزمايش فرضيههاى تحقيق اســت. با تحليل دادهها، مدل معادلات ساختارى زير حاصل شده است. 


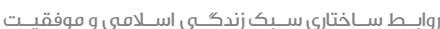

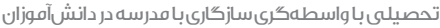

دورo متوسطه دوف

\section{$101-159$}

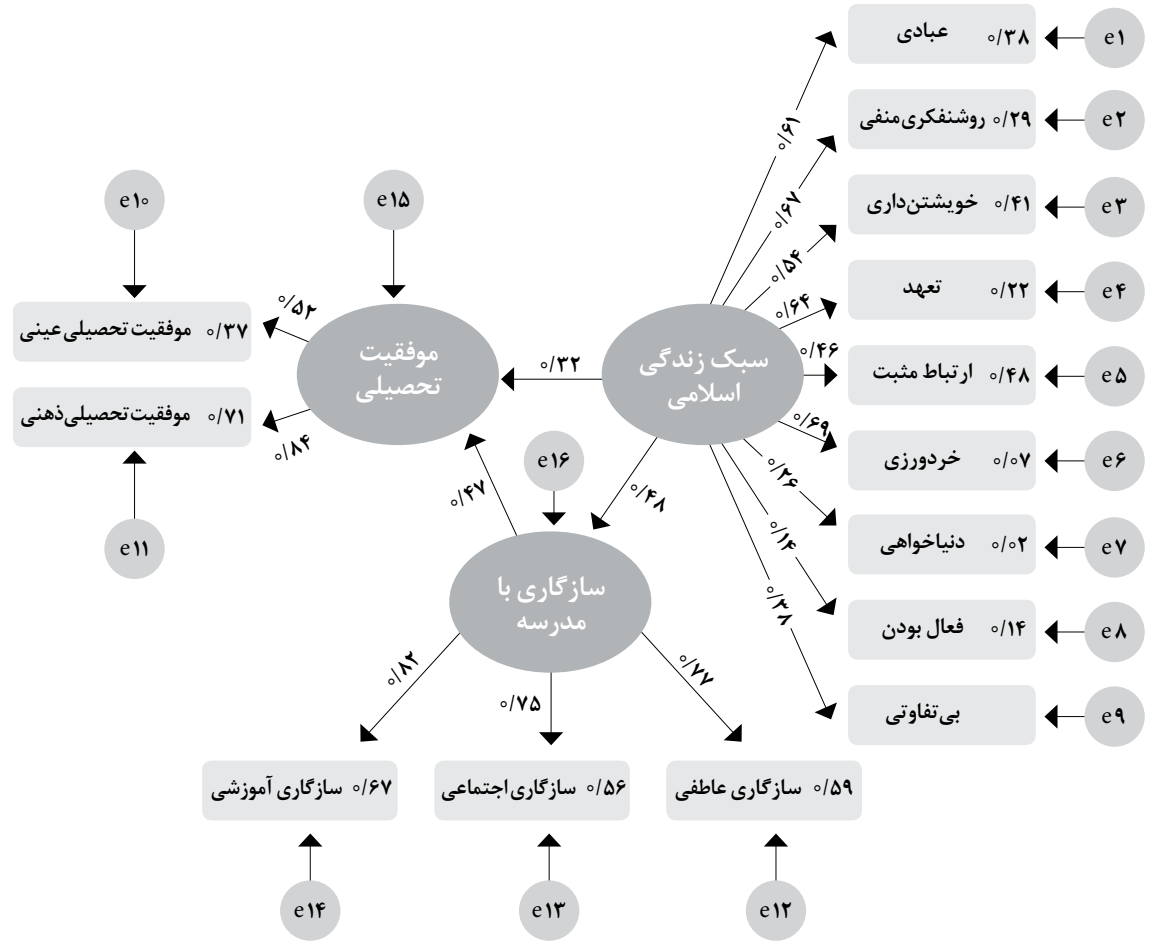

شكل r. مدل معادلات ساختارى

جدول r. روابط مستقيم متغيرهاى مكنون بر يكديگر

\begin{tabular}{|c|c|c|c|c|}
\hline \multirow{2}{*}{ معادارى سطح } & \multicolumn{3}{|c|}{ ضر ايب مسير } & \multirow{2}{*}{ مسيروها } \\
\hline & مقدار & استاندارد نشده & استاندارد شارامتر & \\
\hline$\circ / 0 \circ 1$ & $\boldsymbol{r} / \Delta \boldsymbol{r}$ & $0 / 09$ & o/tr & سبك زندگى اسلامى ر موفقيت تحصيلى \\
\hline$\circ / \circ \circ 1$ & $q / 4 q$ & $\circ / \Delta \Lambda$ & $\circ / \mathbb{C}$ & 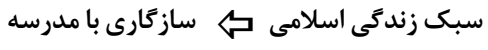 \\
\hline$\circ / \circ \circ 1$ & $\varphi / \Delta \varphi$ & $\circ / \circ 9$ & $\circ / \mathrm{FV}$ & 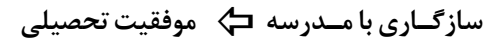 \\
\hline
\end{tabular}

نتايج بهدست آمده از جدول س نشان مىدهد كه رابطه مستقيم متغير سبك زندگى

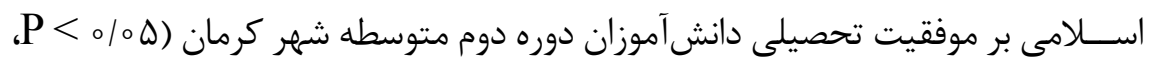


زندگى اســلامىبر ســازگَارى با مدرســـه دانش آموزان دوره دوم متوسطه شهر كرمان

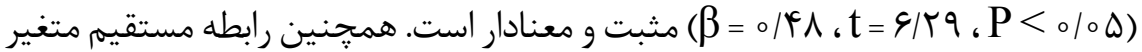
ســاز ₹ارى با مدرســـه بر موفقيت تحصيلى دانشآموزان دوره دوم متوسطه شهر كرمان

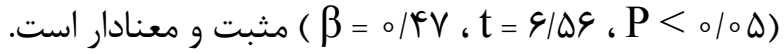

جدول F. رابطه غيرمستقيم متغير هاى مكنون بر يكديگر

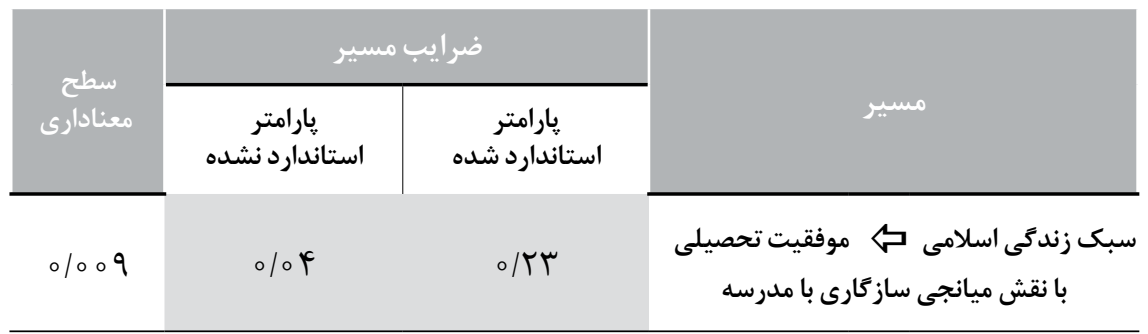

بر اســاس نتايج بهدســت آمده از جدول ؟ا، رابطه غيرمستقيهم متغير سبك زندكى اسلامىبر موفقيت تحصيلى دانشآموزان دوره دوم متوسطه شهر كرمان با نقش ميانجى

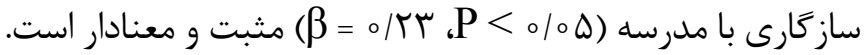

\section{جدولهه. روابط كلى متغيرهاى مكنون بر يكديگر}

\begin{tabular}{|c|c|c|c|}
\hline \multirow{2}{*}{ معنادارى سطح } & \multicolumn{2}{|c|}{ ضرايب مسير } & \multirow{2}{*}{ مسير ها } \\
\hline & استاندارد نشداره & استاندارد شده & \\
\hline$\circ / 0 / f$ & $0 / 09$ & $\circ / \Delta \Delta$ & سبكى زندگى اسلامى حـ موفقيت تحصيلى \\
\hline$\circ / \circ \circ 1$ & $\circ / \Delta \Lambda$ & $\circ / \mathbb{1}$ & 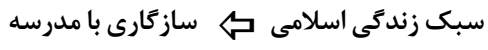 \\
\hline$\circ / \circ \circ 1$ & $\circ / \circ 9$ & $\circ / \mathbb{F V}$ & 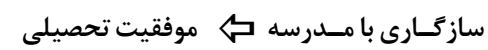 \\
\hline
\end{tabular}

نتايج بهدســت آمده از جدول ه، نشــان مىدهد كه رابطه كلى متغير سبك زندكى

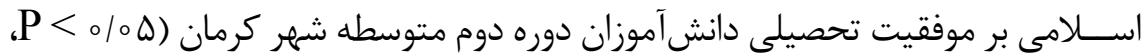

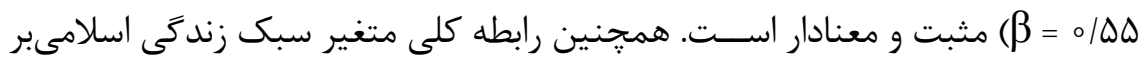
ساز گارى با مدرسه دانشآموزان دوره دوم متوسطه شهر كرمان (ه ( 


\section{$101-149$}

مثبت و معنادار است. همجنين رابطه كلى متغير سازكارى با مدرسه بر موفقيت تحصيلى

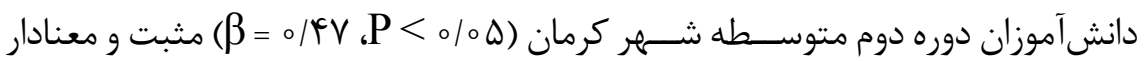

\section{بحث و نتيجهلَيرى}

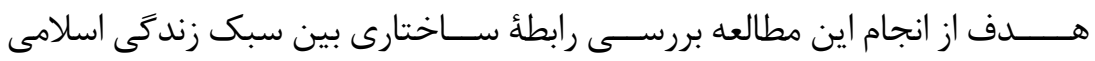

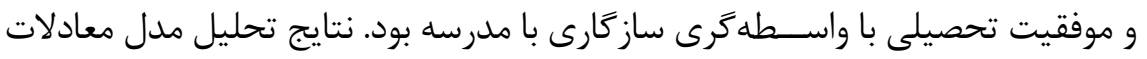

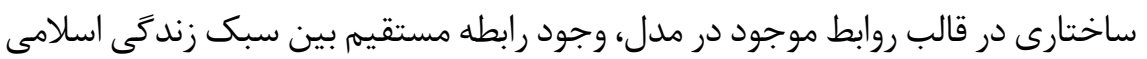

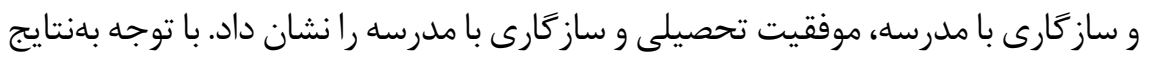

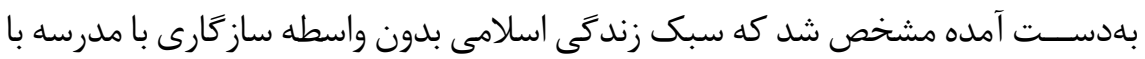

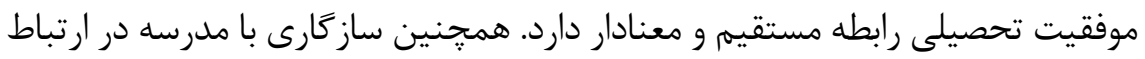

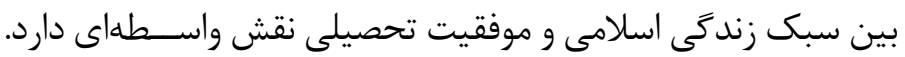

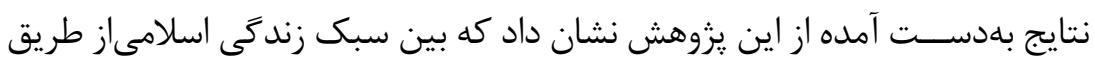

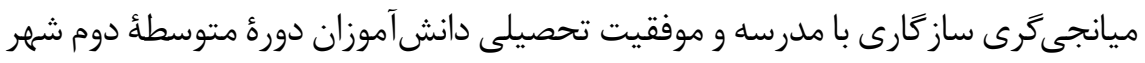

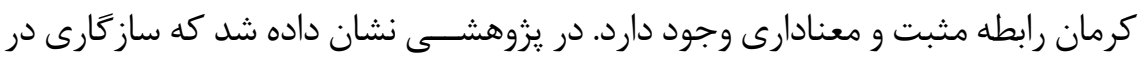

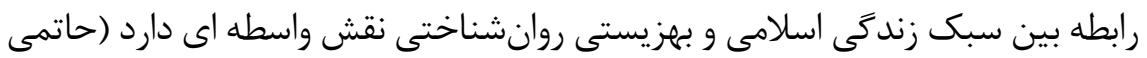

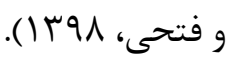

نتيجه بهدست آمده در اين زمينه رامى توان اين كَنه تبيين كرد كه، ديدكاه دانشآموز

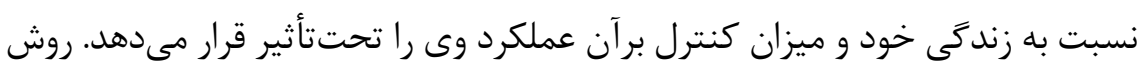

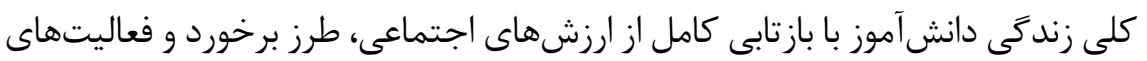

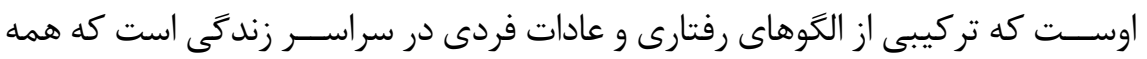

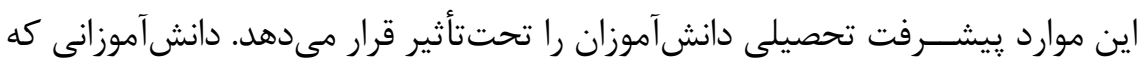

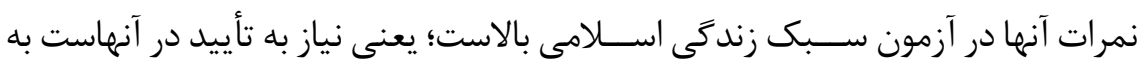

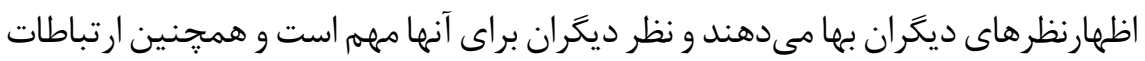

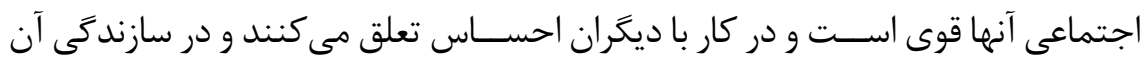

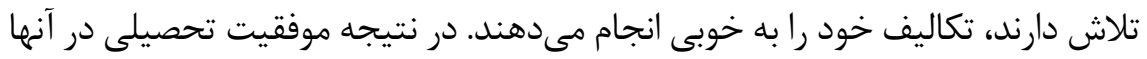

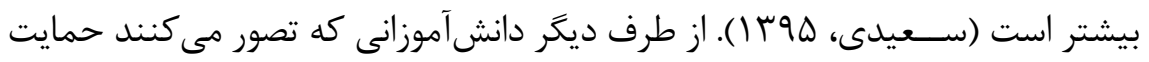


بسيارى را از سوى شبكه اجتماعى (والدين، دوستان و معلمان ) دريافت مى كنند، بيشتر از رفتارهاى مشكل آفرين اجتناب مى كنند، از مدرسه احساس رضايت بيشترى داشته، احســاس خودكار آمدى بيشترى دارند، ســاعات زيادى را براى مطالعه صرف مى كنند و نمرات بالاترى بهدست مى آورند (Weissman, 2010). در نتيجه علاوه بر اين كه اين جنين دانشآموزانى كه داراى سيستم ارزشى خاصى هستند كه در راستاى علائقشان مىباشد و باعث مىشود كه براى خود هدف تعيين كنند و مدام به ارزشيابى اهداف خود بيردازند، متعاقباً موفقيت تحصيلى آنان بالاتر است، بلكه عوامل مختلف آموزشعاهى نظير عوامل فيزيكى، رفتارى و ارتباطى زمينهُ مساعدى را براى سازگارى دانشآموزان فراهم ساخته

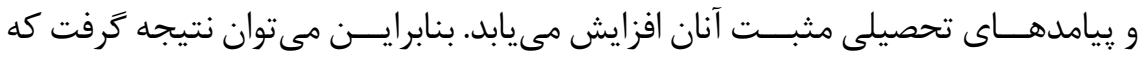
ســاز ₹ارى با مدرســـه مى تواند نقش ميانجى را در رابطه بين ســبك زندكى اسلامى و موفقيت تحصيلى دانشآموزان داشته باشد. ديخر يافتهُ اين يثروهش نشان داد كه بين سبك زندگى اسلامى و موفقيت تحصيلى دانشآموزان دوره متوســـهُ دوم شهر كرمان رابطه مثبت و معنادارى وجود دارد. نتايج يزوهش در اين زمينه، با نتايج يزوهش هاى سعيدى و فرح بخش،هوس ا؛ نيكو كار، خيرى،

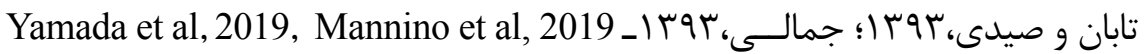
همسو مىباشد. در تبيين اين يافته مىتوان كفت كه ســبك زندگى اســلامى در سلامت جسمى و روانى افراد مىتواند نقش مؤثرى داشته باشد. هر شخص موفق بايد داراى سلامت روانى و جسمى باشد تا بتواند مراحل موفقيت و ييشرفت راطى كند. عوامل عبادى مانند رابطه

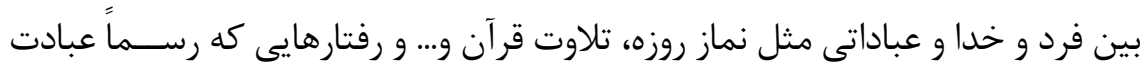

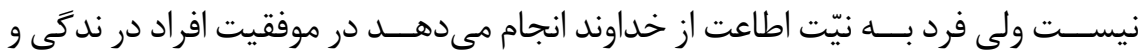
موفقيت تحصيلى نيز مؤثر است (نيكو كار و همكاران، سوس (1). سبك زندگى مرتبط با اسلام و شاخص تفكر دينى، مبنايى براى تصميمزيرى صحيح فراهم مى آورد؛ جرا كه تصميمَيرى براساس مبانى دينى، از نظر منطقى نيز صحيح است و بنابراين باعث كاســتن از نخرشهاى منفى نسبت به مسايل مختلف از جمله تحصيل

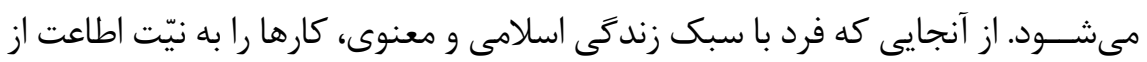
خداوند انجام مىدهد، اين نخرش در موفقيت افراد مؤثر است. با توجه به اين كه در سبك 


\section{$101-149$}

زندگَى اســلامى، كارها با نيّت به خدا و با جشمداشت اندك دنيوى انجام مى گيرد، بايد انتظار داشــت در بحث تحصيل نيز شخص داراى انخيزش درونى باشد و به هر ميزان كه سبك زندگى بيشـــتر رنت و بوى اسلامىداشته باشد، انگَيزش براى يادَيرى و تحصيل بيشـــتر مىشود. در واقع درمتون و تعاليم اسلامى تأكيد زيادى بر امر يادگيرى و خواندن شده است و بر همين اساس براى بسيارى از مسلمانان يادگيرى جزء مهمىاز زندگى است

كه بdصورت درونى و خودجوش انجام مى گيرد (شهابى، مغنى زاده و ثناگوى، Vq I ). سبك زندگى فرد وقتى اسلامىاست كه در زندگى خود، جه شخصى، جه خانوادگى، قواعد، الخوها، قالبها و ملاكهاى اسلامىنقش مهرمىايفا كند؛ يعنى روشها را برا اساس آنجه اســلام كفته و خواسته است به كار گيرد (شريعتى، بوس ا) و از طرفى ارتباط بين ارزشها و هنجارهاى دانشآموز كه در ارتباط با دوســتان و معلمان شــكل مى گيرد و

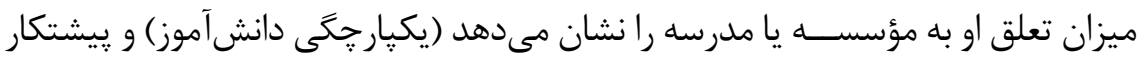
دانش آموز براى بهدست آوردن مدرك يا نمره، اساس موفقيت است و رفتار دانشآموز هم تحصيلى اسـتـ و هم اجتماعى و او بايستى بتواند در درون هر دو حوزه رشد يكيار جگى

داشته باشد تا به موفقيت تحصيلى نائل شود (Yamada et al, 2019). همجٍنين نتايج يزوهش نشان داد كه بين سبك زندگى اسلامى و سازعارى با مدرسه دانشآموزان دوره متوسطه دوم شهر كرمان رابطه معنادارى وجود دارد. نتايج يزوهش در

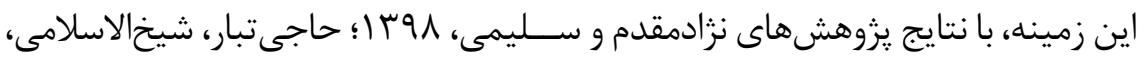

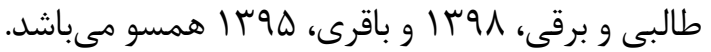

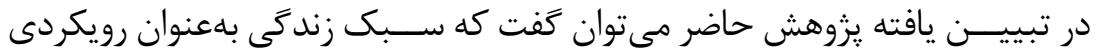
زندگَى انســان، باز تابى كامل از ارزشهاى اجتماعى، طــــرز برخورد، فعاليتها، الخوهاى رفتارى و عــادات فردى جون تغذيه، خواب، فعاليتهاى بدنى، مىباشـــد و هنخامى كه انجام اين اموردر حد مطلوب باشــد، زندكى افراد ازكيفيت بيشترى برخوردار مىشوند. از اين رو منطقى بهنظر مىرسد، افرادى كه داراى سبك زندگى مطلوب باشند، عملكرد بهترى را تجربه كنند و برعكس سبك زندگى نامطلوب، كاهش كيفيت افراد از زندكى را

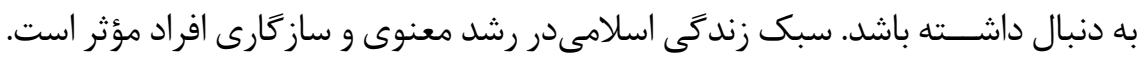
دانشآموزانى كه از سبك زندگى اسلامى برخوردار هستند، سعى مى كنند، راه درست يا 
به كار بَيرد. به عبارت ديخر، اين كه جُگونه با نيازهاى متفاوت خود كنار بيايد و با تدبير

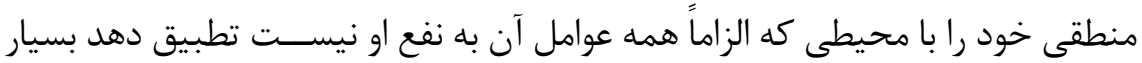
يراهميت است. در نتيجه ممكن است كه كارها خود را به خوبى انجام دهند و فعاليتهاى محوله شده را به نحو احسن انجام دهند. طبيعتاً همه اين عوامل باعث مى شود كه فرد از ساز ₹ارى تحصيلى بيشترى نيز برخوردار باشند (نزاد مقدم و سليمى، 19 1 ). مطالعه سبك زندگى از اين نظر اهميت دارد كه در جوامع مختلف، حكومت ها به دنبال ايجاد تغييراتى در سبك زندگى و بهبود هرجه بيشتر كيفيت زندگى مردم هستند، زيرا

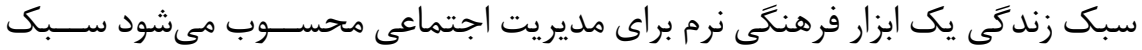

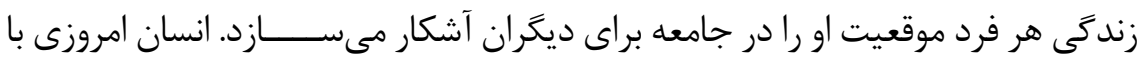

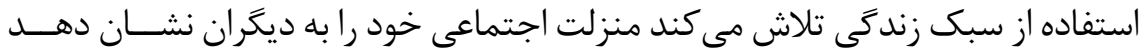

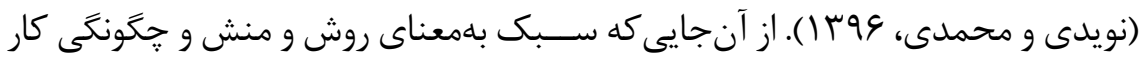
اســت. يك سبك زندكى سالم شامل مواردى مانند تغذيه مناسب، ورزش منظمه، ساعت كافى خواب و يرهيز از سومصرف مواد است و اين سبك زندگى خواهناخواه روى ساز گارى

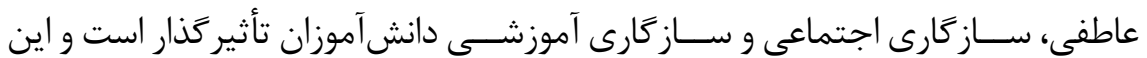
ساز گارىها، عوامل بسيار مهمى هستند كه باعث مىشوند تا دانش آموزان به كمك آنها با محيط مدارس ساز ₹ار شوند و توانايىهاى خود را رشد و توسعه دهند و وقتى از طرف دo- (Go palan et al, 2019 ). غفلت از مسالهُ سبك زندگى خسارتهاى جبران نايذيرى را بر بيكره جامعه وارد مى كند. وقتى مردم نتوانند ميان شـيوهُ زندگى خود و باورها و ارزشهاىشــان ارتباط برقرار كنند بعد از مدتى دسـت از باورها و ارزشهاى خود مىشويند (حيدريور، صادق زاده قمصرى و سجادى، لو r II).

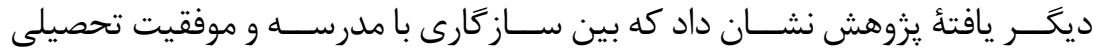
دانشآموزان دوره دوم متوسطه شهر كرمان رابطه معنادارى وجود دارد. نتايج اين يافته با يافتههاى Mittelmeier et al, 2019 Gopalan et al, 2019 تمنائىفر و منصورىنيك، بوسا و خجسته مهر، عباسيور، كرايى و كوجكى، إسا همخوان بود. در تبيين اين يافته مىتوان كفت كه سازگًارى شامل آن دسته از پاسخهاى فرد است كه باعث سـازش مؤثر و هماهنخ وى با موقعيتى مىشود كه در آن قرار دارد. بنابراين 


\section{$101-149$}

دستيابى به يك حد مطلوب از ساز كارى مى تواند دستيابى فـرد را به خواستهها، آرمانها و اهدافش تسهيل نمايد و يكى از اهــــــاف نوجوانـان موفقيـت تحصـيلى اسـت. ادراك

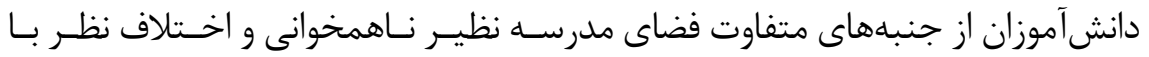

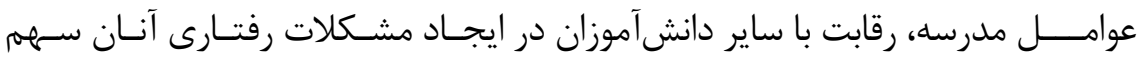

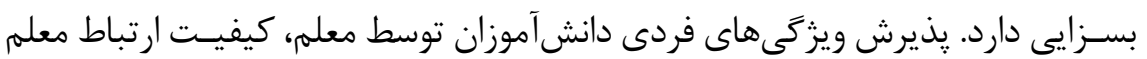
- دانشآموز و يذيرش اجتماعى همسالان از جنبههاى مهرم ساز گارى دانش آموزان است. دانشآموزانى كه تصور مى كنند حمايت بسيارى را از سـوى شـبكه اجتمـاعى (والـدين،

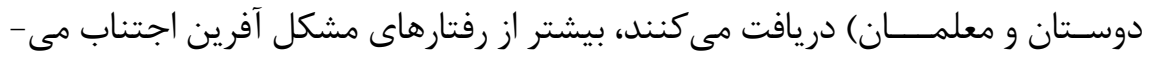
كنند، از مدرسه احساس رضايت بيشترى داشته، احساس خود كارآمدى بيشترى دارند، ساعات زيادى را براى مطالعه صـرف مى كنند و نمـرات بالاترى بهدست مى آورند. بنابر اين

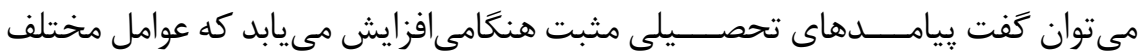
آموزشغاهى نظير عوامل فيزيكى، رفتـارى و ارتبـاطى زمينهُ مساعدى را براى سازگًارى

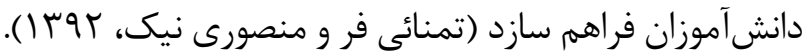

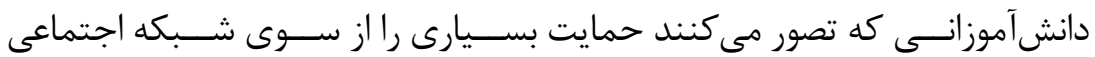
(والدين، دوستان و معلمان ) دريافت مى كنند، بيشتر از رفتارهاى مشكل آفرين اجتناب

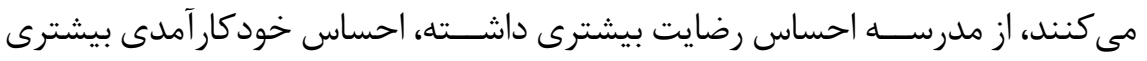
دارند، ســاعات زيادى را براى مطالعه صرف مى كنند و نمرات بالاترى بهدست مى آورند

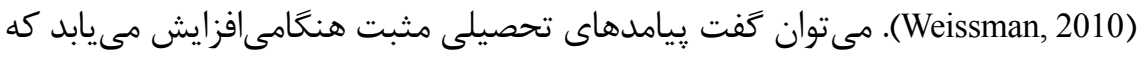
عوامل مختلف آموزشغاهى نظير عوامل فيزيكى، رفتارى و ارتباطى زمينهى مساعدى را براى ساز ₹ارى دانش آموزان فراهم سازد. بنابراين مى توان نتيجه گرفت كه بين ساز ₹ارى با مدرسه و موفقيت تحصيلى دانش آموزان رابطةُ معنادارى وجود داشته باشد.

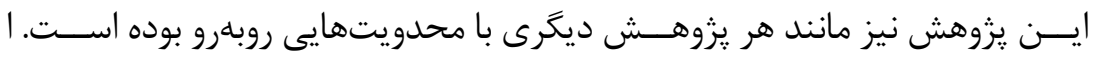

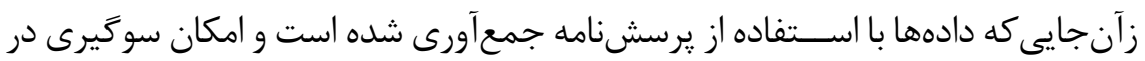
ياسخ گَويى به ســؤالات وجود دارد. در يزوهش حاضر براى ارزيابى الخوى ييشنهادى از روش مدلسازى معادلات ساختارى استفاده شده است، جراكه در آن نه تنها رابطه بين متغير هاى مختلف به شكل همز مان بررسى مى شود. بلكه، مدل سازى معادلات ساختارى به

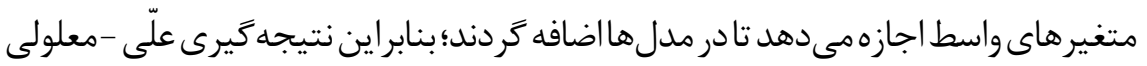




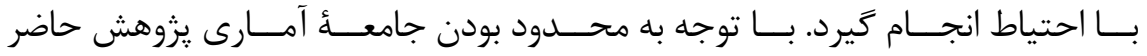

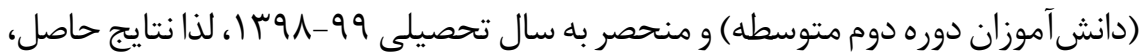
قابل تعميم به ساير جامعهها نمىباشد. استفاده از ابزارهاى خودگزارشى كه ممكن است با سو گيرى نسبى ياسخدهندگان همراه باشد. تفاوتهاى اقتصادى و فرهنگى نيز واقعيتى است كه بر نتايج يزوهش هايى از اين دست تأثير گذار است. با توجه به نتايج اين :يزوهش در بُعد كاربردى به مســـئولان وزارت آموزش و يرورش تهر و ســاير دستاندركاران ييشــــهاد مىشود با كنترل شرايط آموزشــى و درنظر گرفتن دوره تحصيلى كه دانشآموزان در آن مشــغول به تحصيل هستند، زمينه و توان انطباق دانشآموزان با مقررات، مطالب درسـىى، كسب شيوه ياد گيرى جديد، حضور در كلاس و برنامه مطالعه متناسب با دوره متوسطه فراهم سازند و در زمينهُ ساز گارى با مهارتهاى آموزشــى و تحصيلى سعى شود در مناسبتها و امور مختلف از ايده و نظر دانشآموزان بهطور جدى اســتقبال شود و با بركزارى جلســات مشاوره و فعاليتهاى كار ₹اهى براى دانشآموزان و خانوادهها در ارتقاى ســاز گَارى با مدرســـه و موفقيت تحصيلى آنان مؤثر باشند. سبك زندگى اسلامىاز طريق آموزش رسمى در متون درسى آموزش و يرورش و آموزش عالى مورد تدريس قرار خيرد.

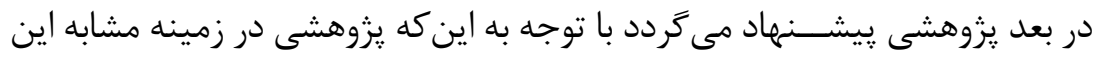
يزوهش در كشور انجام نشده و با توجه به اهميت آن در موفقيت تحصيلى دانشآموزان، ييشنهاد مى شود، تحقيقات بيشتر، وسيعتر و در سطوح مختلف تحصيلى صورت گيرد. انجام اين يزوهش با جامعه آمارى دانشجويان و در دانشعاهها صورت گيرد و نتايج آن با يزهش حاضر مقايسه گردد.

\section{تشكّر و قدردانى}

اين مقاله برگرفته شده از رسالهُ دكتر اي نويسنده اول در رشته روانشناسى تربيتى است. بدينوسيله از معاونت يزوهشى دانشخاه و از تمامى دانش آموزان دوره دوم متوسطه شهر

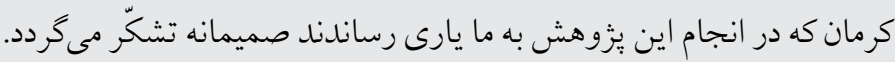




\section{منابع}

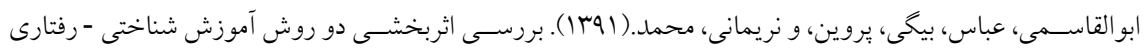

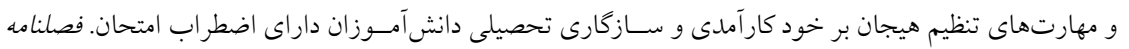
[Doi: 10.22054/JEP.2012.6055]

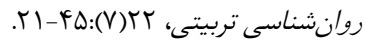

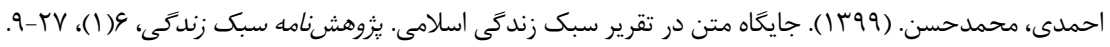

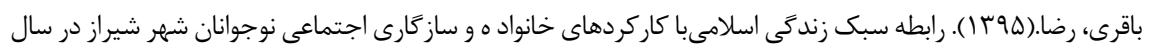

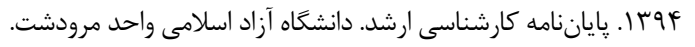

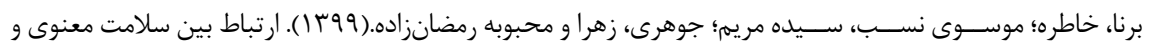

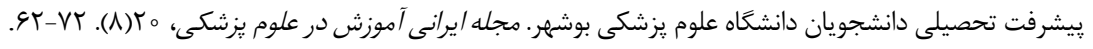

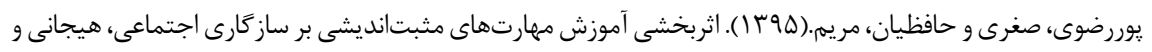

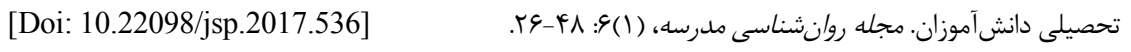

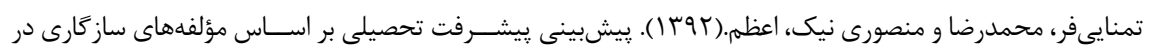

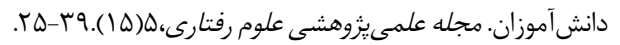

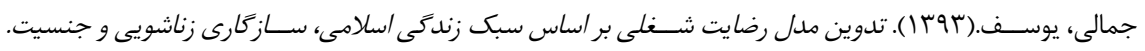
پإيان نامه كارشناسى ارشد رشته روانشناسى، دانشكاه علامه طباطبايى.

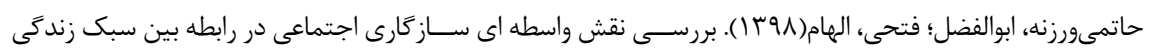

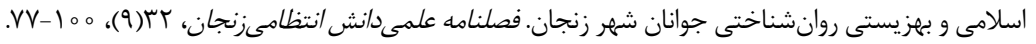

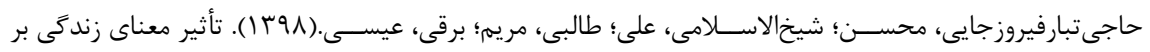

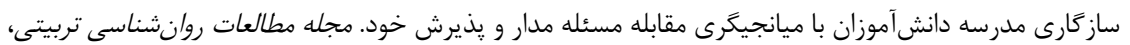
[Doi: 10.22111/jeps.2019.4944] . $\Delta 9-V \&$ ، (YY)।

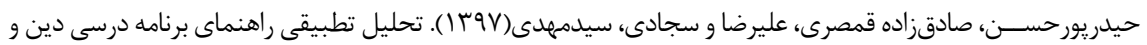

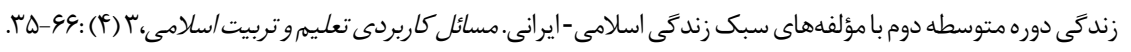

[Doi: 10.29252/qaiie.3.4.35]

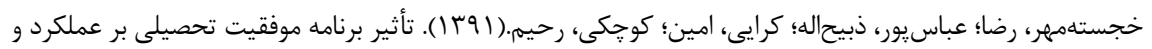

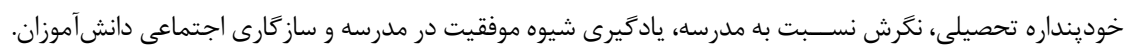

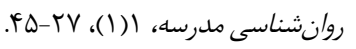

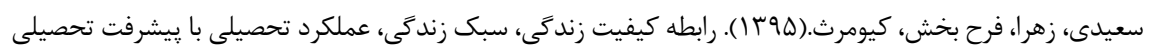

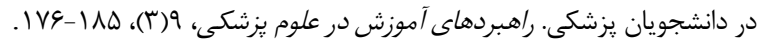

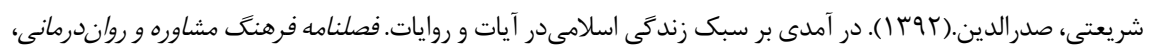
[Doi: 10.22054/qccpc.2013.6082]

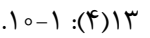

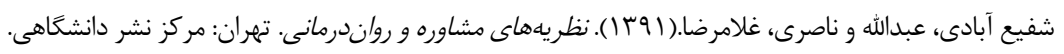

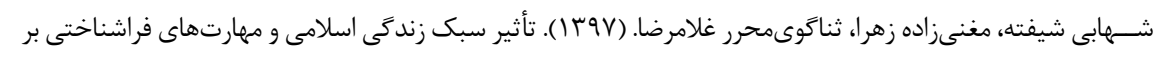

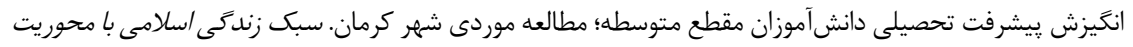


صالحى، رضوان و عابدى، محمدرضا.(بq (1). تدوين مدل نظرى مشــاورره تحصيلى براســاس عوامل مؤثر بر موفقيت [Doi: 10.22055/jac.2017.12559]

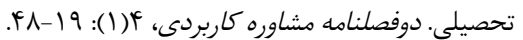

قوامى، مرجان، عابدى، محمدرضا و نيلفروشان، يريسا.(9 9 1 ). ساحتار عاملى پرسشنامه موفقيت تحصيلى دانشآموزان.

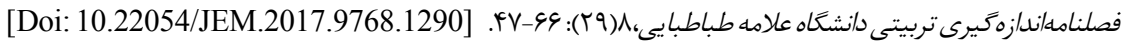

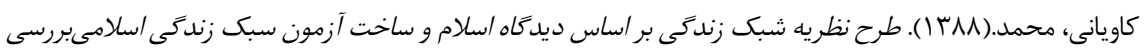

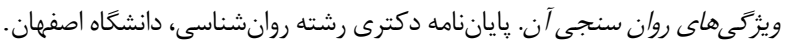

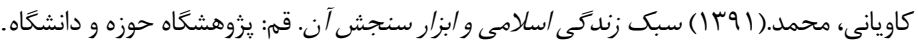
كشـاورز، آزيتا و يوسفى، فريده.(Y I I ). اثربخشــى آموزش مبتنى بر درمان يذيرش و تعهد بر اهمال كارى تحصيلى و

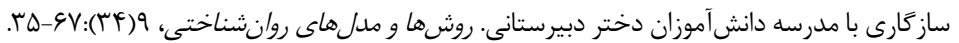

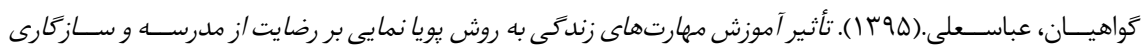

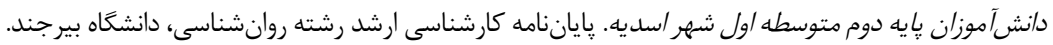

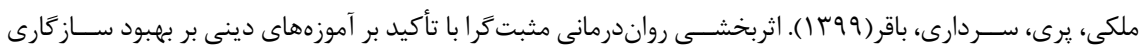

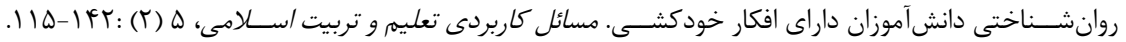

[Doi:10.29252/qaiie5.2.115]

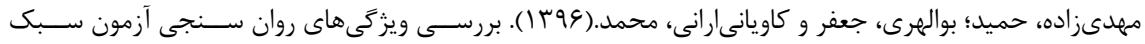

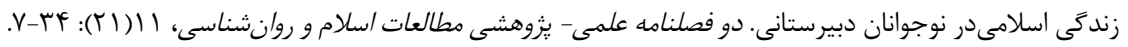

[Doi:10.30471/psy.2018.1422]

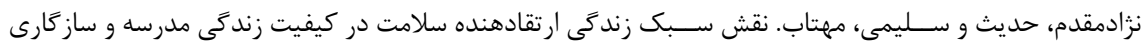

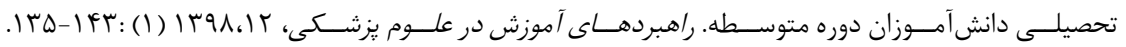

[Doi: 10.29252/edcbmj.12.01.19]

نويدى احد و محمدى، ســريه.(צوس (). مقايسه سبك زندگى مادران حافظ قرآن و همتايان آنان در شهر تهران. مسائل

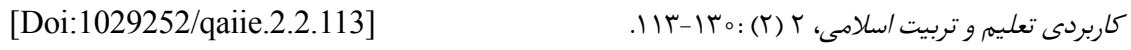

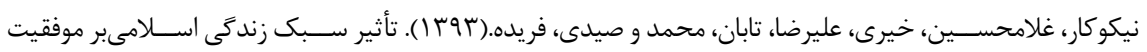

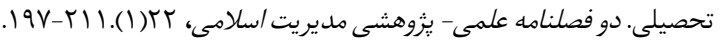

\section{REFERENCES}

Adelantado-Renau, M., Jimenez-Pavon, D., Beltran-Valls, M. R., Moliner-Urdiales, D. (2019). Independent and combined influence of healthy lifestyle factors on academic performance in adolescents: DADOS Study. Pediatric research, 85(4), 456-462.[ https://Doi.org/10.1038/ s41390-019-0285-z].

Alyahyan, E., \& Dustegor, D. (2020). Predicting academic success in higher education: literature review and best practices. International Journal of Educational Technology in Higher Education, 17(1), 3-15. [ https://Doi.org/10.1186/s41239-020-0177-7]. 
Artino, A. (2009). Think, feel, act: motivational and emotional influences on military students online academic success. Journal comput High Educ, 21(2), 146 166.[ https://Doi.org/10.1007/ s12528-009-9020-9].

Baron, T., Grossman, R. I., Abramson, S. B., Pusic, M. V., Rivera, R., Triola, M. M., et al (2020). Signatures of medical student applicants and academic success. PloS one, 15(1), 227-238. [Doi: 10.1371/journal.pone.0227108]

Chun, H., Dickson, G. (2011). A psychological model of academic performance among hispanic adolescents. Journal of youth Adolescence, 40(12), 1581 1594[ .https://Doi.org/10.1007/s10964011-9640-z]

Deaton, M.J. (2008). Academic success of appalachian adolescents: The impact of parental authority and families. Master's thesis. Miami university oxford, ohio.[ http://rave.ohiolink.edu/ etdc/view?acc_num=miami1228165397]

Gerardi, S. (2005). Self concept of ability as a predictor of academic success among urban technical college students. The social science Journal, 42(2), 295 300.[ https://Doi.org/10.1016/j. soscij.2005.03.007]

Gopalan, N., Beutell, N. J., Middlemiss, W. (2019). International Students' Academic Satisfaction and Turnover Intentions: Testing a Model of Arrival, Adjustment, and Adaptation Variables. Quality Assurance in Education: An International Perspective, 27(4), 533-548.[ https://Doi.org/10.1108/ QAE-01-2019-0001]

Kobal. D. Musek , J.(2001). self concept and academic achievement: Slovenia and france. Personality and individual differences. 30(5), 887-899.[ https://Doi.org/10.1016/S01918869(00)00081-7]

Lacasse, Y., Godbout, C., Series, F. (2002). Health related quality of life in obstructive sleep apnea. Eur Respir J, 19(3), 499-503.[ https://Doi: 10.1183/09031936.02.00216902]

Los Santos, D., Bain, S., Kupczynski, L., Mundy, M. A. (2019). Determining Academic Success in Students with Disabilities in Higher Education. International Journal of Higher Education, 8(2), 16-38.[ https://Doi.org/10.5430/ijhe.v8n2p16]

Mannino, G., Giunta, S., Montefiori, V., Tamanza, G., Iacolino, C., Novara, C., et al(2019). Healthy lifestyle, well-being, physical activity, sport, and scholastic/academic performance: interactions and connections. World Futures, 75(7), 462-479.[ https://Doi.org/10.1080/02604027.2019.1654 772]

Mittelmeier, J., Rienties, B., Rogaten, J., Gunter, A., Raghuram, P. (2019). Internationalisation at a Distance and at Home: Academic and social adjustment in a South African distance learning context. International Journal of Intercultural Relations, 72(9), 1-12.[ https://Doi.org/10.1016/j. ijintrel.2019.06.001]

Usher, E. L., Li, C. R., Butz, A. R., Rojas, J. P. (2019). Perseverant grit and self-efficacy: Are both essential for children's academic success?. Journal of Educational Psychology, 11(5), 877-902.[ https://Doi.org/10.1037/edu0000324]

Weissman, M.M. (2010). The assessment of Social adjustment. A Review of Techniques In ARC Gen Psychiatry, 32(3), 125-136.[ https://Doi:10.1001/archpsyc.1975.01760210091006] 
Yamada, M., Sekine, M., Tatsuse, T., Asaka, Y. (2019). Association between lifestyle, parental smoke, socioeconomic status, and academic performance in Japanese elementary school children: the Super Diet Education Project. Environmental health and preventive medicine, 24(1), 22.[ https://Doi.org/10.1186/s12199-019-0776-x]

Yusuf, M. (2011). The impact of self efficacy, achievement motivation, and self regulated learning strategies on students' academic achievement. Procedia Social and Behavioral Sciences, 15, 2623-2626.[ https://Doi.org/10.1016/j.sbspro.2011.04.158] 